\title{
Issues in Anti-Corruption Law: How Can Code of Conduct Laws Be Drafted in Order to Reduce Corruption in a Public Sector like Romania's?
}

\author{
Bryane Michael, Linacre College (Oxford)
}

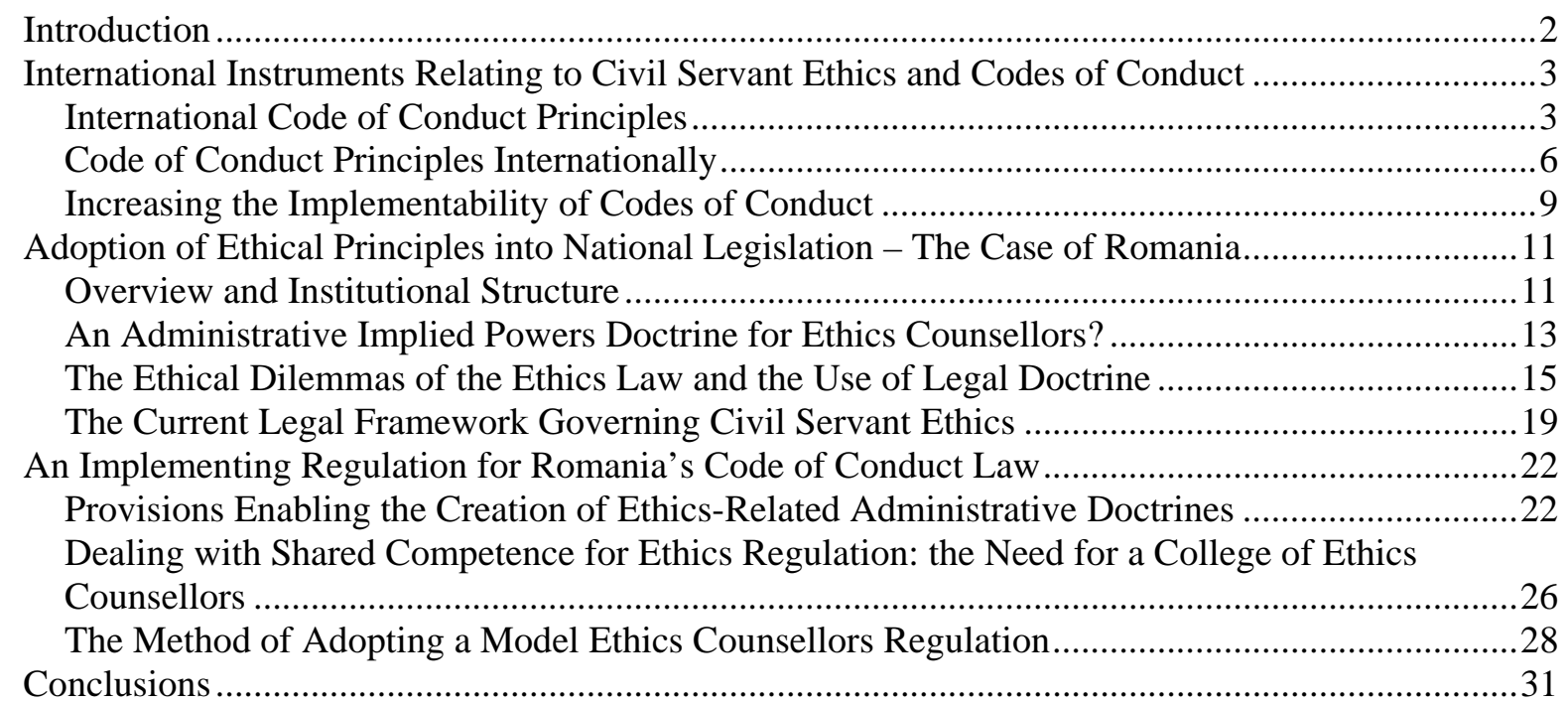

\begin{abstract}
International organisations, like the UN and EU, have encouraged their member states for years to increase civil servants' compliance with particular codes of conduct. Romania represents probably one of the most advanced countries in attempting to legislate on civil servant ethics through its Code of Conduct Law. Yet, the Romanian Code of Conduct Law possesses significant weaknesses, emanating both from the inherent difficulties of using hard law in a soft law area (like civil servants' ethics) and the Law's silence as to specific procedures which government agencies should use in implementing the Law. Given these weaknesses, Romanian government agencies should adopt regulatory instruments which compensate for these weaknesses at the legislative level. In this paper, we present the provisions - particularly related to the establishment of agency-level ethical doctrines -which regulatory drafters can use to implement these codes of conduct in a civil law system without running afoul of the basic requirements of civil law jurisprudence for clarity and predictability. We discuss the legal basis in Romanian administrative law for the elaboration of specific ethics-related doctrines and the ways in which such a "doctrinal approach" to administrative ethics can help achieve the objectives of the flawed Code of Conduct Law. We specifically discuss the ways in which Romanian governments can adopt such regulatory instruments and the types of provisions which should be included in order to help overcome the flaws of the Code of Conduct Law.
\end{abstract}




\title{
Issues in Anti-Corruption Law: How Can Code of Conduct Laws Be Drafted in Order to Reduce Corruption in a Public Sector like Romania's?
}

\author{
Bryane Michael, Linacre College (Oxford)
}

\section{Introduction}

The issue of ethics - particularly public sector ethics - remains one of the most contentious and difficult areas of work in public sector management. Government ethics often represents an area of lawmaking where no agreement exists in order to pass hard law. For example, should a civil servant who breaks his agency's rules in order to help a citizen in distress be punished - or rewarded? Should civil servants escape legal liability when they ignore direct instructions from their superiours when they believe that ignoring those instructions serves the public's interests? Many civil law legal systems like Romania's- which rely on the clarity and predictability of black letter law - have been attempting to regulate the conduct of its civil servants through instruments familiar to the common law system - particularly government codes of conduct. However, unlike in the US, UK (or even French and Swedish systems), civil servants in countries like Romania do not have the authority to interpret their code of conduct regulations, establish legal reasoning - or doctrines - for taking ethical decisions and can not absolve themselves of liability for misconduct when they can demonstrate that they acted according to a particular administrative precedent or clearly in the public interest.

We argue that legislative provisions requiring the implementation of codes of conduct in a public sector (like Romania's) can only succeed those provisions allow for the development of legal doctrine(s) to emerge. Simply put, such legislation must allow for civil servants in civil law jurisdictions to use the rules of thumb, list tests, balancing tests and other relatively ambiguous criteria which civil servants in common law jurisdictions use in adjudicating ethical dilemmas at the administrative level. Yet, such provisions run counter to civil law jurisprudence requiring clarity and predictability. We try to show ways in which potential regulators who are setting up government code of conduct programmes might implement a doctrinal approach to codes of conduct in a civil law system without running afoul of the basic requirements of civil law jurisprudence for clarity and predictability.

Our paper, thus, presents the ways in which regulatory drafters can adopt a doctrinal approach toward implementing government codes of conduct in a civil law system like Romania's. The first section presents international regulatory work on model ethical codices and codes of conduct - showing the legal principles which are slowly filtering into legislation in countries like Romania. The second section describes specifically the Romanian Code of Conduct Law - presenting the provisions and the legal issues involved. We discuss the law's shortcomings and the ways in which work at the regulatory level can help overcome legislative weaknesses. We specific specifically focus on the bolstering of ethics counsellors' rights through an implied powers doctrine and the methods by which civil servants can develop ethics-related administrative legal doctrine in Romania. In the third section, we discuss the ways in which these implied powers to create ethics-related legal doctrines can be codified into a model executive regulation. We argue that, by codifying Romanian government ethics counsellors' rights (and obligations) into an executive regulation helps establish the procedural rights (and obligations) which can ensure the clarity and predictability of the otherwise unclear method of ethics-related legal doctrine making. 


\title{
International Instruments Relating to Civil Servant Ethics and Codes of Conduct
}

\section{International Code of Conduct Principles}

\begin{abstract}
Almost all international organisations working on issues related to public sector management and public administration have attempted to draft soft law legal instruments providing guidance on the creation of public officials' codes of conduct. ${ }^{1}$ Figure 1 provides an overview of these instruments - always adopted as recommendations and thus imposing no specific obligations on the public officials of the respective signatory states. ${ }^{2}$ As shown, these instruments reflect two philosophical orientations toward civil servant (and public officials') ethics and conduct. ${ }^{3}$ The OECD and EU take a soft-law approach toward regulating public officials' behaviour, as such behaviour relates to the taking of ethical decisions. ${ }^{4}$ Such an approach recognises that little agreement on ethical issues exists between countries (and thus their public administrations). The soft law approach accepts that civil servants (and public officials more generally) require large amounts of discretion in order to work - involving the frequent taking of ethical decisions. Thus, these soft law instruments focus more on providing general principles by which public officials can resolve
\end{abstract}

\footnotetext{
${ }^{1}$ In this paper, we follow the hard law and soft law dichotomy used throughout the literature (and Dr. Solomon provides a recent overview of the application of such soft law in administrative law tradition, particularly in civil law jurisdictions. Soft law instruments (such as recommendations, advice as verbal instructions and other admonitions on civil servants to act in a particular way deemed "ethical" by the authors of these instruments represent parts of a country's ethics legal framework containing provisions in which inefficient consensus exists in order to establish enforcement mechanisms and insufficient clarity exists in order to define the exact actions prohibited or required. If consensus existed about these provisions, lawmakers would have created hard law - writing down the specific measures of black letter law and included measures to ensure compliance (and punish non-compliance). See Jason Solomon, Law and Governance in the 21st Century Regulatory State, 86 TEX. L.REV., 2008. Dr. Friedrich provides a fascinating discussion of the increasing "legality" of these soft law instruments. See Jurgen Friedrich, Legal Challenges of Nonbinding Instruments: The Case of the FAO Code of Conduct for Responsible Fisheries, 9 Ger. L. J. 11, 2008. We omit work by regional organisations, such as the Organisation of American States and large non-government organisations (like Transparency International) in order to focus our discussion.

${ }^{2}$ International organisations also finance and implement projects in member states with a focus on public officials' ethics. For a good general overview of activities related to government ethics and codes of conduct around the world, see Elia Armstrong, INTEGRITY, TRANSPARENCY AND ACCOUNTABILITY IN PUBLIC ADMINISTRATION: RECENT TRENDS, REgIONAL AND INTERNATIONAL DEVELOPMENTS AND EMERGING IsSUES, August 2005, available online.

${ }^{3}$ The elision of ethics-related regulation on civil servants and public officials significantly complicates a proper discussion of government ethics-related regulation. Many countries have tackled more directly ethicsrelated regulation of civil servants' conduct (namely non-politically appointed individuals in a public sector body). Regulating these individuals is easier on the grounds that they take technocratic, non-political decisions in which ethical dilemmas do not become wrapped up with political decisions. A public official refers to politicians serving in government (such as ministers) as well as civil servants. Thus a public official's code of conduct takes into account the difficult political trade-offs which they need to take - often making these codes of conduct less stringent. The definition of ethics laws and administrative codes of conduct also presents a complication for the reader. Does a poorly enforced regulation requiring public employees to come to work "on time" comprise an ethics law, or a general normative act? In order to avoid a lengthy discussion about the definition of an ethics law (or a code of conduct), we refer to a code of conduct as a document which is labelled as a code of conduct and an ethics law as a document with the words "ethics law" in the title. While such an approach may appear at first glance high unsatisfactory, this approach does focus on laws in which parliament (or the relevant lawmaking body) had the intent to specifically regulate public sector ethics and conduct.

${ }^{4}$ In this paper, we refer to public officials' (or civil servants') ethics, ethical conduct and codes of conduct related to that conduct as decisions taken by these individuals in situations where: a) they work in a public sector agency, b) they possess administrative discretion to take decisions (or a sufficient lack of oversight which gives them the ability to take these decisions), c) their discretionary decision involves a choice with a non-obvious or multiple acceptable outcomes, and d) these outcomes require value judgements related to how good or bad (from an ethical viewpoint) these outcomes are.
} 
dilemmas when they can not determine a single clear, proper course of action. ${ }^{5}$ Because the principles enshrined in these general statements of principles can be interpreted numerous ways, civil servants have difficulty applying these principles consistently and predictably. The difference in interpretations also exposes public officials to administrative risk as the individuals or agencies enforcing these principles may rule against the public official's interpretation. ${ }^{6}$

\section{Figure 1: List of International Recommendations on Public Officials’ Ethics}

\begin{tabular}{|c|c|c|c|}
\hline $\begin{array}{l}\text { Sponsoring } \\
\text { Organisation }\end{array}$ & $\begin{array}{l}\text { Name of } \\
\text { Instrument }\end{array}$ & Details & $\begin{array}{l}\text { Philosophical } \\
\text { approach }\end{array}$ \\
\hline $\begin{array}{l}\text { United } \\
\text { Nations } \\
\text { (UN) }\end{array}$ & $\begin{array}{l}\text { International } \\
\text { Code of Conduct } \\
\text { for Public } \\
\text { Officials }^{7}\end{array}$ & $\begin{array}{l}\text { The Annex to Resolution 51/59 contains an International } \\
\text { Code of Conduct for Public Officials. The Code contains } \\
\text { general principles (such as those described below), } \\
\text { provisions related to conflict of interest, the disclosure of } \\
\text { assets, prohibitions on the acceptance of gifts, restrictions } \\
\text { on the handling of confidential information and engaging in } \\
\text { political activity. The Code is relatively brief (about } 2 \\
\text { pages). }\end{array}$ & $\begin{array}{l}\text { Hard-law } \\
\text { approach }\end{array}$ \\
\hline $\begin{array}{l}\text { Council of } \\
\text { Europe } \\
\text { (CoE) }\end{array}$ & $\begin{array}{l}\text { Codes of } \\
\text { Conduct for } \\
\text { Public Officials }\end{array}$ & $\begin{array}{l}\text { The CoE code --- spanning } 14 \text { pages --- deals with most of } \\
\text { same issues as the UN International Code. As usual, CoE } \\
\text { work tends to be more detailed. A number of provisions } \\
\text { deal with specific issues considered now a vital part of a } \\
\text { code of conduct - such as cooling off periods. }\end{array}$ & $\begin{array}{l}\text { Hard-law } \\
\text { approach }\end{array}$ \\
\hline OECD & $\begin{array}{l}\text { Recommendation } \\
\text { on Improving } \\
\text { Ethical Conduct } \\
\text { in the Public } \\
\text { Service }^{9}\end{array}$ & $\begin{array}{l}\text { The least helpful of all the work on codes of conduct, the } \\
\text { Recommendation provides } 10 \text { very abstract categorical } \\
\text { imperatives. }\end{array}$ & $\begin{array}{l}\text { Soft law } \\
\text { approach }\end{array}$ \\
\hline EU & $\begin{array}{l}\text { Proposal for an } \\
\text { (EU) Ethics } \\
\text { Framework }\end{array}$ & $\begin{array}{l}\text { Only slightly better than the OECD work, the proposal } \\
\text { comprises a think-piece on general attributes required of a } \\
\text { code of conduct. }\end{array}$ & $\begin{array}{l}\text { Soft law } \\
\text { approach }\end{array}$ \\
\hline
\end{tabular}

Source: authors based on cited documents. The dichotomisation of the legal instruments presented in the figure represent our own interpretation - as the division between soft law and hard law provisions is not clear.

\footnotetext{
${ }^{5}$ Such an approach has often been called the deontological approach. Civil servants should master moral reasoning skills and not act on stringently defined rules. The other main attribute of this approach is that the civil servant should act according to his or her duty - in sharp contract to the Anglo-Saxon approach looking at a civil servant's incentives for compliance. A discussion of public sector ethics would take our paper well offcourse. For more, see Charles Garofalo and Dean Geuras, COMMON GROUND, COMMON FUTURE: MORAL AGENCY IN PUBLIC ADMINISTRATION, 2006.

${ }^{6}$ Even though soft law statements of administrative ethical principles aim at providing the public official with more discretion (and freedom to make ethical decisions which he or she considers serves the interests of justice or some other public value), they might result in public officials taking more conservative decisions. These public officials - who are notoriously risk averse and liable for their ethical decisions - often decide not to assume administrative (or personal) liability in order to uphold general principles of justice, equity, equality, progress, privacy, and so forth. As such, these codes of conduct tend to become more repressive over time, as risk averse public officials ignore provisions aimed at providing leeway and greater flexibility. For an interesting description of this phenomenon, see Leno Saarniit, A Public Service Code of Ethics Applied in a Transitional Setting: The Case of Estonia, 8 PUBLIC INTEGRITY 1, 2005.

${ }^{7}$ UN Resolution 51/59, Action Against Corruption (A/RES/51/59, 82nd plenary meeting, 12 December 1996), available online.

${ }^{8}$ Codes of Conduct for Public Officials, Recommendation Rec(2000)10, available online.

${ }^{9}$ Recommendation on Improving Ethical Conduct in the Public Service (23 April 1998), available (with discussion) online.

${ }^{10}$ Main features of an Ethics Framework for the Public sector, Proposal by the Dutch Presidency, available online.
} 
The UN and Council of Europe (CoE), on the other hand, take a more hard-law approach to work on public officials' codes of conduct. Specifically, the Council of Europe Codes contain most of the major elements which have made their way into legislative instruments in the various EU member states. Work along these lines focuses on the "minimum standards" of most member states - leaving out the philosophical parts of the code of conduct contained by deontologically-focused work on civil servant codes of conduct. These codes of conduct typically assemble provisions usually addressed by hard law instruments in various countries - particularly the US. Such an approach epitomises a rule-of-law approach to regulation by defining obligations specifically enough such that compliance can be monitored and remedies (as well as punishments for non-compliance) can be defined and enforced. However, by relying on hard law, these instruments threaten to remove (over time) much of the discretion - and thus discretionary rights to uphold particular ethical values such as justice or the public good - from civil servants work.

\section{Figure 2: Substantive Provisions Contained in International Public Officials' Code of Conduct Instruments}

\begin{tabular}{|c|c|c|c|c|}
\hline \multirow{2}{*}{$\begin{array}{l}\text { Conflict of interest } \\
\text { point }\end{array}$} & \multicolumn{3}{|c|}{ Article numbers from each instrument } & \multirow[t]{2}{*}{ Usual areas of law } \\
\hline & $\mathbf{U N}$ & CoE & Romania & \\
\hline due regard for the law & 7 & 4 & 6 & Constitution \\
\hline $\begin{array}{l}\text { no arbitrary or } \\
\text { capricious behaviour }\end{array}$ & 3 & 6 & 12 & Civil servant/ PA Law \\
\hline impartiality & 3 & 7 & 12 & $\begin{array}{l}\text { Constitution and CS or } \\
\text { PA Law }\end{array}$ \\
\hline Courtesy & none & 5 & 12 & none \\
\hline $\begin{array}{l}\text { avoid conflict of } \\
\text { interests }\end{array}$ & 4,6 & $8,13,15,20$ & 3 & Conflict of Interest Law \\
\hline declaration of interests & 5 & 14 & $\begin{array}{l}\text { none (contained in } \\
\text { separate law) }\end{array}$ & $\begin{array}{l}\text { Declaration of Assets } \\
\text { Law }\end{array}$ \\
\hline political activity & 11 & 16,21 & 10 & $\begin{array}{l}\text { CS, PA Law or CoI } \\
\text { Law }\end{array}$ \\
\hline gifts & 9 & 18,19 & 14 & Anti-Corruption Law \\
\hline $\begin{array}{l}\text { leaving public service } \\
\text { and dealing with former } \\
\text { public officials } \\
\text { "cooling off period" }\end{array}$ & none & 25,26 & none & CoI or AC Law \\
\hline $\begin{array}{l}\text { Confidential } \\
\text { information }\end{array}$ & 10 & 11,22 & 7 & State Secrets Law \\
\hline $\begin{array}{l}\text { Use of government } \\
\text { resources (efficiency) }\end{array}$ & 2 & 23 & 5 & CS or PA Law \\
\hline $\begin{array}{l}\text { "conduct becoming of a } \\
\text { public official" }\end{array}$ & 1 & 9 & 12 & none \\
\hline Respondeat superiour & none & 10,24 & none & PA law \\
\hline $\begin{array}{l}\text { Duty to report specious } \\
\text { activities }\end{array}$ & none & 12 & none & $\begin{array}{l}\text { PA law, admin, civil } \\
\text { and criminal law }\end{array}$ \\
\hline Sanctions & none & 27 & 22 & Disciplinary code \\
\hline
\end{tabular}

Source: authors - based on materials cited.

The scope of activities and the specificity of the provisions in these codes of conduct in various countries could reflect the philosophical differences between the hard law and soft law approaches to government ethics. The abstract nature of the OECD's work on civil servant codes of conduct reflects the view that real-world situations are too complex to define specific regulations governing public officials' conduct. The OECD's work covers a large scope of civil servant work (as shown in Figure 2). However, none of the articles in their Recommendation provide specific advice for public officials in specific 
circumstances. ${ }^{11}$ The UN and CoE work, in contrast, focuses on specific elements of public officials' action - usually civil servant action as judging by the nature of the activities regulated -- which third-party agencies can monitor and enforce. These elements focus on cooling off periods, the submission of asset and conflict of interest declarations, and other objectively monitorable actions. ${ }^{12}$

\section{Code of Conduct Principles Internationally}

The ethical principles contained in many international soft law instruments have spread (to a greater of lesser extent) to EU member states. ${ }^{13}$ Figure 3a shows an assessment, based on analysis from Drs. Moilanen and Salminen about the extent to which various member states' codes of conduct impose specific obligations on their civil servants. ${ }^{14}$ We quantify the scope covered by these obligations on a scale between 1 and 5 - whereby a code of conduct has a greater scope if the code covers a wider range (or variety) of public sector activities. Accordingly, countries such as Ireland, Finland and Romania have codes of conduct covering a large range of civil servants' activities. By definition, more specific codes of conduct derive from the incorporation of hard law provisions - and Ireland, Romania and Finland also lead the list of countries with highly specific government codes of conduct. However, little discernible relationship exists between a code of conduct's specificity - the extent to which provisions are specific as usually contained in hard law provisions - and the code's scope of activities covered. ${ }^{15}$ The European Commission - as an institution provides a notable exception. The Commission has one of the most comprehensive codes of conduct; yet many of the highly specific provisions are redolent of the hard-law approach to civil servant ethics. ${ }^{16}$

\footnotetext{
${ }^{11}$ As shown by the working papers and other informational materials on the OECD's website, the French deontological tradition of public officials' ethics has clearly affected the OECD’s Secretariat (which is located in Paris). In French administrative law, civil servants are given wide margin for action as long as their actions are in interest of the public interest.

${ }^{12}$ As discussed below, the Anglo-Saxon approach to civil servant ethics (which the UN and CoE approach adopt more fervently than the OECD and EU) tackles scope of civil servant action by creating judicial doctrines. Civil servants - often through litigation - create and gossip about principles which guide their work. These doctrines, specific as to the situations in which they cover, spring up for a wide range of situations. As such, no one- to-one correspondence exists between the scope and specificity of a code of conduct and the type of legal system involved; or whether such provisions are founded in hard law or soft law. For more on the challenges faced by different legal systems in adopting government ethics and code of conduct work, see Bossaert, Danielle and Christophe Demmke, MAIN CHALLENGES IN THE FIELD OF ETHICS AND INTEGRITY IN THE EU MEMBER STATES, 2005.

${ }^{13}$ US scholars have most profoundly developed the English language literature on government codes of conduct - where they publish hundreds, if not thousands, of research articles each year. As argued below, the US's common law system provides for such a vigorous debate and fine-tuning of codes of conduct. For a review of EU work, Christophe Demmke, ETHICS IN THE CIVIL SERVICES OF THE MEMBER STATES OF THE EU MANY PARADOXES BUT NO NEED TO BE PESSIMISTIC, 2007, available online.

${ }^{14}$ Timo Moilanen and Ari Salminen, Comparative Study on the PUblic Service Ethics of The EU MEMBER STATES, available online.

${ }^{15}$ The correlation coefficient for the specificity and scope scores we give the 22 countries which Moilanen and Salminen cover is 0.64 . Such a correlation coefficient shows some correlation, though certainly not enough to make any judgments about a positive relationship between a code of conduct's specificity and its scope.

${ }^{16}$ Several factors may explain why the EU, as an organisation, has implemented a code of conduct with a broader scope (yet with more specific provisions) than most of its member states' public sectors. The Commission represents an executive agency (albeit a supranational one), whereas the public sectors of member states comprise the wider range of interests contained in their judiciaries, legislatures, local governments and even public sector enterprises. The Commission, like the member states’ public administrations, has administrative tribunals which have been rendering judgments on cases with ethical dimensions. However, unlike most member states, these decisions from the Commission's administrative tribunals have helped form the basis of the code of conduct. Such an approach to code of conduct work reflects the conflict resolution approach which we describe in Figure 18.
} 


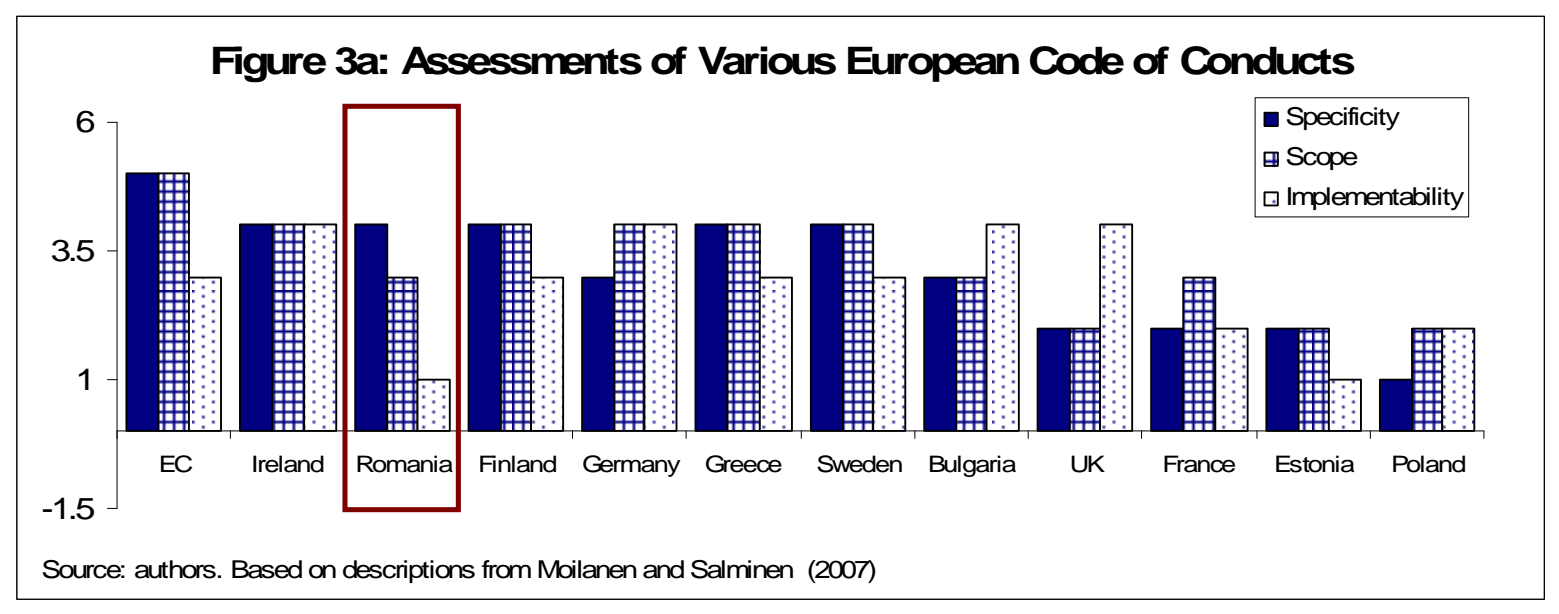

Our analysis fails to find any trade-off between the scope and specificity of an administrative code of conduct. At first glance, code of conduct drafters need to decide whether to include general soft-law principles or a list of specific hard-law provisions - as trying to include both would seemingly lead to a code of conduct running hundreds of pages long. Figure $3 \mathrm{a}$ - as previously shown -- debunks the notion of a trade-off between a code of conduct's specificity and scope. Countries like Poland have narrow and vague codes of conduct while Greece has a broad-reaching and specific code. Yet, while little specific correlation between scope and specificity exists, wide-scoped codes of conduct can also include specific provisions - and visa versa. For example, the UK and France represent the most interesting countries (from a code of conduct point of view) because they are oftencited, well-developed ethics regulations evolving in rather different legal traditions. Both countries' government administrations are perceived to be equally (un)trustworthy - with $33 \%$ of their populations trusting government. ${ }^{17}$ Romania's inclusion among countries which rank at the top of the list in terms of the scope covered and the specificity of its provisions of its civil servants' code of conduct result from a combination of soft law and hard law provisions. However, in Romania's case, such a combination makes Romania's code of conduct difficult to implement. Romania falls at the bottom of the list of countries in terms of the implementability of its code of conduct. ${ }^{18}$ Not surprisingly, only $28 \%$ of the population trusts the Romanian government.

The scope of these codes of conduct-particularly in Central Europe - tends to be relatively similar, in terms of the values these codes admonish public officials to uphold. ${ }^{19}$ Figure $3 \mathrm{~b}$ shows data extracted from a study by Professor Palidauskaite, comparing different values covered by codes of conduct in Central and Eastern Europe. ${ }^{20}$ With the exception of requiring courteous treatment of citizens using public services, the majority of codes of

\footnotetext{
172006 Annual Edelman Trust Barometer, available online.

${ }^{18}$ Implementability refers to the ability of the government to use little staff time and resources in order to achieve the results set forth in the code of conduct. For example, the general lack of supervision over political parties in Romania render ineffective any restrictions on using office time to assist with the political campaign activities of political candidates. Funding, supervising and enforcing such provisions in Romania would be harder than in a country like Finland - where the general administrative culture accepts new regulations such as these more readily.

${ }^{19}$ If these codes of conduct place obligations on public officials, then they implicitly provide indemnification against prosecution in cases where they disobey regulations or instruction while relying on the implicit authority given by the code of conduct (to uphold the public good or other values). Such authority (and the reliance on such authority) constitutes an implied powers doctrine which we discuss later.

${ }^{20}$ Jolanta Palidauskaite, Codes of Ethics in Transitional Democracies: A Comparative Perspective, 8 PuBLIC INTEGRITY 1, Winter 2005-6: 35 - 48.
} 
conduct contain largely similar provisions. ${ }^{21}$ Not surprising given these countries postSocial histories, all codes of conduct forbid civil servants from using government resources for political party purposes (campaigning or politicking more generally). Most - though not all - codes of conduct uncontroversially include the promotion of efficiency and/or effectiveness as a core ethical value. Such provisions set the basis for the soft law underpinning many of these codes of conduct.

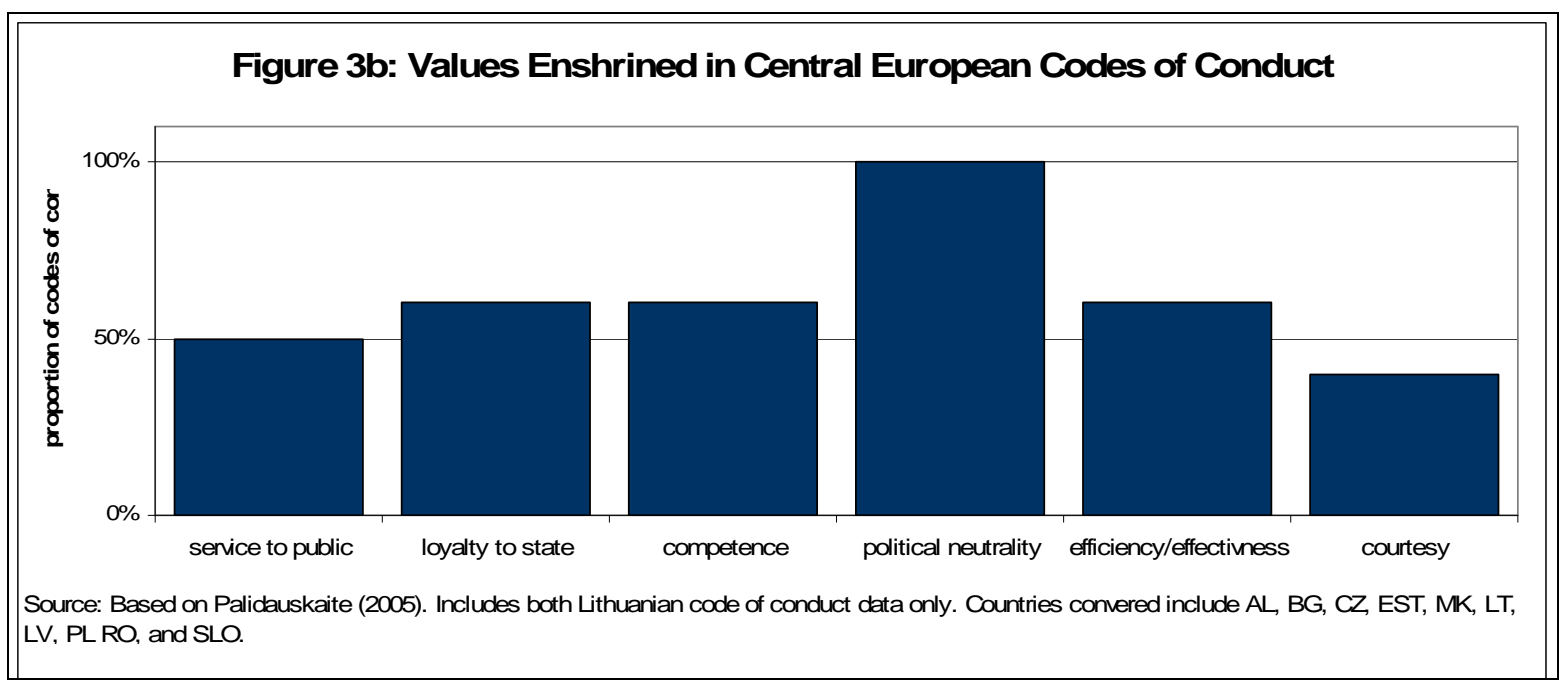

The commitment to hard(er) law provisions varies between Central European countries. Countries like Poland, Czech Republic and Estonia omit sanctions and the enforcement mechanisms from their codes of conduct. Ironically, while all codes of conduct value political neutrality, less than $50 \%$ of these codes explicit regulate political activity. Yet, of the provisions that remain, given the phrasing of the provisions in these codes, these values may be seen - from a legal practitioner's point of view - as soft law resolutions. As reflected by low specificity and implementability scores, most of soft law provisions contained in these codes of conduct do not form an adequate basis for creating substantive obligations (or rights) imposable on civil servants. ${ }^{22}$

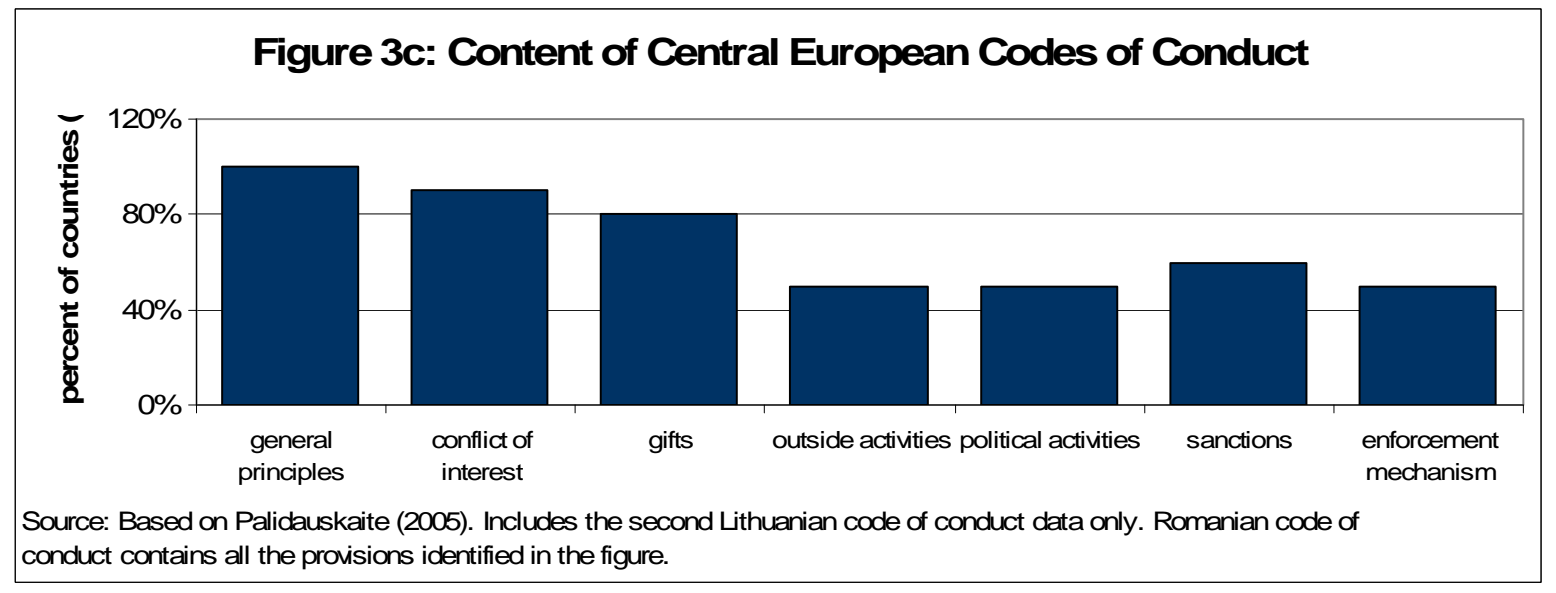

\footnotetext{
${ }^{21}$ The similarity of these codes of conduct suggests that copying -- or diffusion - from abroad. See Figure 18 for a discussion of the ways in which Central European countries could have developed these codes of conduct.

${ }^{22}$ No sane civil servant in Estonia, Romania or another Central European country would reasonably disobey their bosses' orders because they believe their own decisions would better serve the public interest or the economise on government resources. No sane civil servant would rely on an administrative court, tribunal or arbiter to rule in their favour in such a circumstance. As civil servants can not rely on these codes of conduct in their daily work, they fail to provide substantive rights for these civil servants.
} 
As these codes of conduct fail to create substantive obligations or rights, the benefits of having a government code of conduct have been far from clear. Drs. Svensson and Wood's study of the implementation of codes of conduct in Sweden echo the majority of findings in this area. ${ }^{23}$ They note that while objective benefits of government code of conduct programmes are difficult to identify, most public sector officials view these codes as useful and productive. Drs. Ashkanasy, Falkus and Callan find in their overview of code of conduct use (by Australian civil servants) that personal values play a more important role in public officials' conduct until such time as when a "critical mass" of civil servants adheres to a code of conduct. ${ }^{24}$ Moreover, the effects of a code of conduct on government ethics over time seem highly questionable. Drs. Omurgonulsen and Oktem note, from their empirical study of Turkish civil servants, that their ethical values have not changed - despite the implementation of codes of conduct (and other ethics-related) programmes. ${ }^{25}$ Codes of conduct - and similar soft law instruments aimed at regulating government ethics, simply do not change public officials' behaviour in the long-run. ${ }^{26}$

\section{Increasing the Implementability of Codes of Conduct}

Given the disappointing results from previous government ethics and codes of conduct programmes, a number of authors have attempted to propose ways of increasing the implementability of such code of conduct laws. ${ }^{27}$ As summarised in Figure 4, many of these approaches focus on making soft law harder. ${ }^{28}$ For example, Professor Franzese specifically encourages the audit and greater enforcement of ethics laws. The OECD has reiterated this view - with recent publications on government ethics encouraging the use of hard law programmes such as the implementation of conflict of interest declarations and asset declaration. $^{29}$

\footnotetext{
${ }^{23}$ Goran Svensson and Greg Wood, Implementation, communication and benefits of public sector codes of ethics: A longitudinal study of Sweden, 22 InT’L J. OF PuB. SECTOR MAN. 4, 2009.

${ }^{24}$ Neal Ashkanasy, Sarah Falkus and Victor Callan. Predictors of Ethical Code Use and Ethical Tolerance in the Public Sector, 25 J. of Business Ethics 3, 2000.

${ }^{25}$ Ugur Omurgonulsen and Kemal Oktem, Is There Any Change in the Public Service Values of Different Generations of Public Administrators? The Case of Turkish Governors and District Governors, J. of Bus. Ethics, 2009.

${ }^{26}$ We particularly refer to Profs. Mackenzie and Hafken's opus on the effects of ethics programmes in the US. Their insightful study should be required reading for any scholar of government ethics programmes. See Calvin Mackenzie and Michael Hafken, SCANDAl Proof: Do EThics LAws MaKe Government ETHICAL?, 2008.

${ }^{27}$ In further support of the lack of effectiveness of government ethics programmes - from the EU - Milanen and Salminen find very little statistical correlation between the implementation of ethics programmes and decreases in misconduct in the 27 European Union member countries which they study. According to their regression analysis (p. 27), almost all their correlation co-efficients are not statistically different from zero. See Moilanen and Salminen supra note 14.

${ }^{28}$ For a useful critique of recent attempts to “export” government ethics, see J Kaune, Exporting Ethics: Lessons from Russia's Attempt to Regulate Federal Lobbying, HASTINGS INT'L \& COMP. L. REV., 1996.

${ }^{29}$ Howard Whitton, Janos Bertok, MANAGING CONFLICT OF INTEREST IN THE PUBLIC SECTOR: A TOOLKIT, Organisation for Economic Co-operation and Development, available online.
} 


\section{Figure 4: Overview of Proposed Remedies for Soft Law Code of Conduct Work} (ranked in terms of rigidity) ${ }^{30}$

\begin{tabular}{|c|c|}
\hline Proposal & Weaknesses \\
\hline Establishment of an ethics watchdog & $\begin{array}{l}\text { These watchdogs tend to lack investigatory, much less prosecutorial, } \\
\text { direction -- given the ambiguity about the provisions they are } \\
\text { supposed to enforce. }\end{array}$ \\
\hline Punish ethical breaches & $\begin{array}{l}\text { Given the ambiguity of ethical dilemmas (and therefore ethical } \\
\text { breaches), most punishment remains informal - forcing the official } \\
\text { to plead guilty to another offence or stepping down. }\end{array}$ \\
\hline Engage in ethics audits & $\begin{array}{l}\text { The most promising area of ethics and code of conduct work, such } \\
\text { audits - if conducted according to internal audit standards- can } \\
\text { provide creative ways of promoting compliance with the spirit of a } \\
\text { code of conduct. }\end{array}$ \\
\hline $\begin{array}{l}\text { Certification of staff in knowledge } \\
\text { of ethics code and its application }\end{array}$ & $\begin{array}{l}\text { Largely considered a waste of time by participants in such } \\
\text { programmes and provides questionable benefits. }\end{array}$ \\
\hline $\begin{array}{l}\text { Simplify and clarify ethics laws into } \\
\text { a uniform ethics code }\end{array}$ & $\begin{array}{l}\text { Simple harmonisation does not guarantee compliance - indeed, } \\
\text { harmonisation may not be desirable across jurisdictions with } \\
\text { different ethical values. }\end{array}$ \\
\hline $\begin{array}{l}\text { Extend ethics provisions to third } \\
\text { parties (including contractual terms } \\
\text { for failing to comply with } \\
\text { government's ethics provisions) }\end{array}$ & Doubtful legality and practical effect on private sector conduct. $^{32}$ \\
\hline $\begin{array}{l}\text { Extend liability through qui tam and } \\
\text { reduce liability for pro-active ethics } \\
\text { management }\end{array}$ & $\begin{array}{l}\text { European governments are very sceptical of qui tam laws and have } \\
\text { legal traditions which tend not to mitigate liability for preventive } \\
\text { programmes like in the US. }\end{array}$ \\
\hline Ethics training and toolkits & $\begin{array}{l}\text { These "trainings" (often highly moralistic in tone) often fail to } \\
\text { address specific rights and obligations. Anglo-Saxon style toolkits } \\
\text { lack a legal basis in the civil law administrative tradition. }{ }^{33}\end{array}$ \\
\hline $\begin{array}{l}\text { Senior managers to provide ethical } \\
\text { leadership }\end{array}$ & $\begin{array}{l}\text { Chicken and egg problem - if senior managers were ethical, the } \\
\text { issue of organisational ethics would be attenuated - particularly } \\
\text { when these senior managers' misdeeds are explained by incentives } \\
\text { they are given. }\end{array}$ \\
\hline Rediscovery of public sector virtue ${ }^{34}$ & $\begin{array}{l}\text { According to this argument, civil servants need to rediscover their } \\
\text { commitment to the public --- an assertion which the public choice } \\
\text { school would find impossible. }\end{array}$ \\
\hline
\end{tabular}

Source: based on Franzese (2005). ${ }^{35}$

\footnotetext{
${ }^{30}$ We rank elements according to the extent to which they create specific obligations and rights which can be objectively assessed and enforced - in order words, hard law.

${ }^{31}$ Svensson and Wood at supra note 23 most explicitly state that respondents, in their survey of Swedish civil servants, thought such programmes wasted their time (though not the time of their colleagues!)

${ }^{32}$ Can the public sector contracting authorities impose contractual terms based on provisions which are not (hard) administrative law? Naturally, contracting parties can agree to any (statutorily allowed) terms both sides deem acceptable. However, such terms would make business more expensive (by raising compliance costs) and fail to serve as acceptable grounds if the government procuring authority terminates the contract. As such, soft law ethics-related contractual restrictions are time inconsistent as the government would lack incentives to enforce them.

${ }^{33}$ Common law jurisdictions (such as the US and UK) also give civil servants discretion (to a limited extent) to resolve ethically ambiguous situations themselves. However, their approach to educating civil servants about how to resolve ethical dilemmas rather differs with methods on the Continent. In most EU member states, practical methods of resolving ethical dilemmas should be found in administrative law and not the ad hoc doit-yourself toolkits given to civil servants in the common law jurisdictions. For an example of such a toolkits (which have little or no basis in administrative law), see Carol Weiss Lewis and Stuart Gilman, THE ETHICS Challenge in Public Service: A Problem-Solving Guide.

${ }^{34}$ Such an argument comes from Michael Macaulay and Alan Lawton, From Virtue to Competence: Changing the Principles of Public Service, PuB. Admin. REV. September - October, 2006.

${ }^{35}$ Prof. Franzese's suggestions apply to the US state of New Jersey. However, much like in Europe, the US states are trying to come to terms with the implementation of codes of conducts across a wide range of administrative jurisdictions. Her proposals could not be more relevant for the European Union (and its member states) than the American union (and its member states - known as the United States of America). See Paula
} 


\section{Adoption of Ethical Principles into National Legislation - The Case of Romania}

\section{Overview and Institutional Structure}

Romania represents one of the most progressive civil law jurisdictions to attempt to regulate civil servants' conduct in ethically ambiguous situations. ${ }^{36}$ Figure 5 shows each of the provisions of one of Romania's key ethics-related pieces of legislation - the Code of Conduct Law. ${ }^{37}$ The Code of Conduct Law aims to promote ethical values within the civil service in order to help civil servants provide "excellent" public services (article 5). The Law establishes a fiduciary duty on the part of civil servants toward their agency (arts 6-7), regulates communication with members of the public (arts 8-13), and re-iterates the prohibition on taking gifts and bribes (arts 14 to 19). The Law places executive responsibility for implementing the present Law with the National Agency of Civil Servants (or NACS) and broadly defines its working procedures (arts 20-23). The Law outlines rudimentary disciplinary procedures (article 24) and measures related to informing the public about the Law. In short, the Code of Conduct Law provides for many of the provisions found in other EU ethics laws (as shown previously in Figures 3).

\section{Figure 5: Law on Civil Servants’ Code of Conduct}

Chapter I: Field of Application and General Principles

Article 1: Field of Application

Article 3: General Principles
Article 2: Purpose

Article 4: Terms

\section{Chapter II: General Norms of Moral and Professional Conduct for Civil Servants}

Article 5: To provide a high quality public service

Article 7: Loyalty to public authorities and institutions

Article 9: Public activity

Article 11: The use of image

Article 13: International relations

Article 15: Participation in decision making

Article 17: The use of political prerogatives

Article 19: Restricted participation in public contracts

Chapter III: Institutional Arrangements

Article 20: The public institution in charge

Article 22: Settling the case

Chapter IV: Final provisions

Article 24: Accountability

Article 26: Publicity
Article 6: Loyalty to the law

Article 8: Freedom of opinion

Article 10: Political activity

Article 12: Relationships

Article 14: Restrictions on gifts

Article 16: Objectivity

Article 18: The use of public resources

Article 21: Notification

Article 23: Publicity on reported cases

Article 25: Harmonization of internal rules Article 27: Enforcement

Source: Romanian Code of Conduct Law

Franzese, Restoring the Public Trust: An Agenda for Ethics Reform of State Government and a Proposed Model for New Jersey, 57 RuTGERs L. REV. 4, 2005

${ }^{36}$ Professor Mungiu-Pippidi provides a possible explanation for Romania's aggressive stance on civil servants' ethics. She notes that the Romanian civil service may suffer from a lack of accountability. However, the lack of accountability in question is not to the electorate or even particular interest groups (a model of accountability stressed by the US and UK systems). The accountability in question pertains to the administrative ethos of the civil service itself. In this way, the Romanian public administration follows the French system much more closely than the US and UK system. Civil servants are accountable to themselves and the deontological ethic governing their work (in the French as enshrined in administrative law). See Alina Mungiu-Pippidi, Culture of Corruption or Accountability Deficit? 11/12 E. EuR. ConST. REV. 4/1, 2002-3.

${ }^{37}$ Code of Conduct for the Civil Servants (Law 157/2004) [hereinafter the Code of Conduct Law], available online. 
Like in most Central and Eastern European countries, many of the provisions contained in the Code of Conduct Law are repeated in other laws. For example, article 41 of the Civil Service Law, in substance, repeats article 7 of the Code of Conduct Law -- requiring "professionalism, loyalty and fairness, and to refrain themselves from any action that might cause damage to the public organisation." ${ }^{38}$ Article 42 of the Civil Service Law repeats article 11 of the Code of Conduct Law - requiring public officials to "refrain themselves from expressing or manifesting their political believes." Similar overlaps exist related to the guarding of state secrets and confidentiality (article articles 44-45 of the Civil Service Law and article 7 of the Code of Conduct Law), and the prohibition on accepting gifts (art 46 of the Civil Service Law and article 14 of the Code of Conduct Law). Article 70.3 of the Civil Service Law defines disciplinary actions applicable to civil servants violating provisions of the Civil Service Law (including warnings and reprimands as well as more significant penalties such as deducting $5-10 \%$ from the civil servant's pay-check for a duration of 1-3 months or the suspension of the right to promotion for 1-3 years).

The Code of Conduct Law contributes ambiguity to an already vague and overlapping institutional structure aimed at regulating civil servant ethics in Romania. Romanian administrative law, in general, comprises a patch-work of dated laws (some adopted before the establishment of the 1991 republic), emergency government decisions, and various parliamentary decrees. ${ }^{39}$ The Code of Conduct Law places the competence for monitoring the ethical behaviour by civil servants with the NACS. ${ }^{40}$ Clearly then, ethics counsellors working in the NACS fall under NACS jurisdiction. However, a separate Ethics Order also establishes agency-level ethics counsellors which work with staff as well as the NACS. ${ }^{41}$ Clearly, through the Romanian Organic Law, ethics counsellors working in line ministers derive their competence for monitoring the ethical conduct of their peers through the minister's or agency director's delegated authority. ${ }^{42}$ As shown in Figure 6, ethics counsellors' competence to supervise the behaviour of colleagues (for conformance with Romania's ethics-related laws) represents a shared competence -- deriving from both their administration as well as the NACS. Any advice they give must derive from the same administrative sources which individuals (like advisors) have and any ability to advice on disciplining staff must derive from the same authority which the disciplinary committees use in the function of their work. However, no law (or regulation) specifically defines the competencies of these ethics counsellors - particularly those working in Romanian government agencies.

\footnotetext{
${ }^{38}$ Regarding the Regulations of Civil Servants (Law 188/1999), [hereinafter the Civil Service Law], available online.

${ }^{39}$ Local researchers such as Dr. Matei, confirm that the highly disarticulated nature of the Romanian public administration. See Lucica Matei, RomAnian Public MANAGEMENT REFORM: THEORETICAL AND EMPIRICAL STUDIES, 2009, available online.

${ }^{40}$ The authority for ethics counselors comes from art. 20 of the Code of Conduct Law - which empowers the NACS to review agencies' conduct and the Law on Civil Servants.

${ }^{41}$ National Agency for Public Servants Order for Setting-Up a Unitary Framework Regarding the Methods Used to Fill-In and Send Data and Information Regarding the Observance of Norms of Conduct by Public Servants and the Application of Disciplinary Procedures (Order no. 4500/2008 of 21 April 2008),[hereinafter the Ethics Order].

${ }^{42}$ The authority to delegate competencies derives from the Law on the Organisation and Operation of the Romanian Government (Law No.90/2001)[hereinafter the Romanian Organic Law].
} 
Figure 6: Institutional Schematic of Ethics Counsellors in Romanian Law

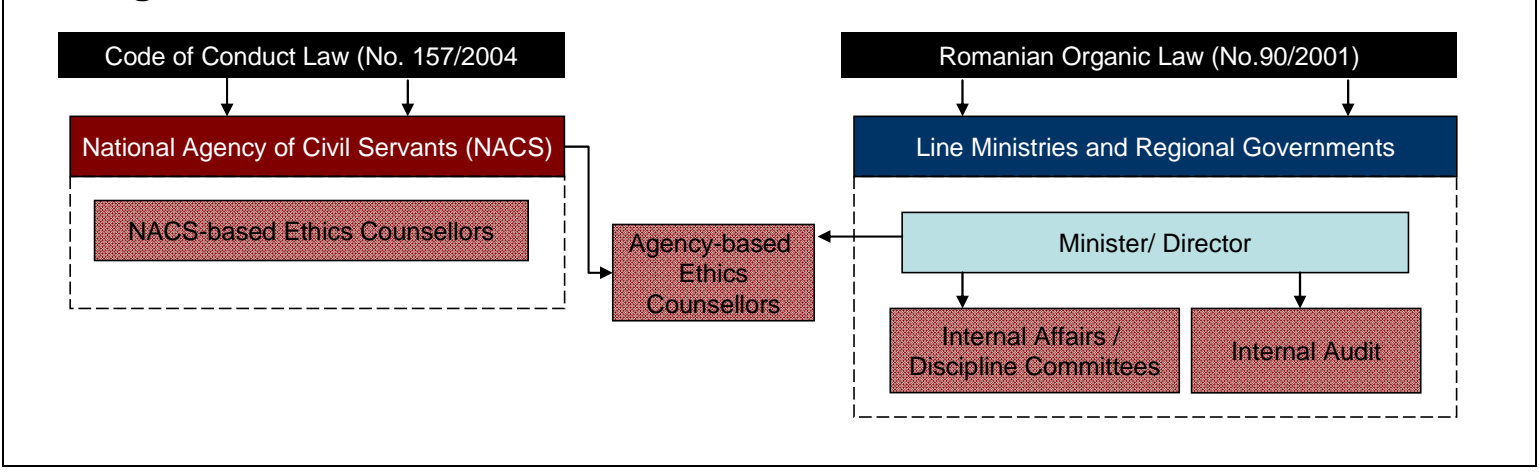

\section{An Administrative Implied Powers Doctrine for Ethics Counsellors?}

Only a doctrine of administrative organisation can help resolve the problems posed by Romania's vague and overlapping ethics-related institutional structure. ${ }^{43}$ Such a doctrine of administrative organisation - as such a doctrine applies to the implementation of ethicsrelated legislation -- must define how competencies devolve to ethics counsellors and how organisational units (such as the NACS and any particular government agency) share these competencies. Such a doctrine should also remedy the Code of Conduct Law's failure to address ethics counsellors' potentially overlapping jurisdiction with other bodies such as internal audit (or inspection) - particularly as International Auditing and Assurance Standards Board (IAASB) standards require surveillance over an organisation's "culture of compliance" and general ethical culture. ${ }^{44}$

Such an administrative doctrine should also correctly assign and allocate competencies and administrative rights so that ethics counsellors can comply with their increasingly burdensome obligations. Figure 7 shows how the Code of Conduct Law has increased the obligations on ethics counsellors (and thus their liability in cases where they fail to perform when staff under their watch commit ethical breaches). The Code of Conduct Law explicitly grants the NACS rights over executive agencies in terms of collecting complaints and following up on them. ${ }^{45}$ Such an obligation pulls authority toward to the NACS and (incidentally) creates obligations whose costs are likely to exceed their benefits - resulting in large-scale non-compliance. Managers working in line ministries, however, have few (if any) additional obligations imposed on them. They should have acted ethically before -- as well as after -- the adoption of the Code of Conduct Law.

Ethics counsellors in executive agencies, though, receive the bulk of the substantive obligations. They are required, by article 20 of the Code of Conduct Law, to supply the

\footnotetext{
${ }^{43}$ By legal doctrine, we refer to the widely accepted practice of establishing legal principles, creating theories which are tested in court or during another form of arbitration. Over time, the successful application of these theories contributes to the larger doctrine in the area. To take an obvious example (from a common law jurisdiction in order to clearly demonstrate the approach we are discussing), many administrators (and private citizens alike) may rely on a theory of tort liability in the US. When a US citizen (or government agent) sues someone for tort damages, they test that theory - in a a common law jurisdiction, often build around a number of case precedents. While civil jurisdictions (such as Romania) do not precedents in the development of legal theories, they do look at how laws are being applied by other courts and in practice during their interpretation of specific statutes or provisions in administrative law. Romania - for reasons which we subsequently describe in great detail - may use a doctrine-based approach in certain areas of administrative law - particularly related to the regulation of civil servant ethics.

${ }^{44}$ Law on Public Internal Audit, available online.

${ }^{45}$ Code of Conduct Law, art. 20.
} 
NACS with information about ethical breaches. As agency directors have been responsible for establishing these positions, they expect their ethics counsellors to deal with complaints related to unethical conduct in their administration. Agency managers - thus - possess liability (both under the Code of Conduct Law and the general administrative procedures in force) for ethical lapses of staff in their department. However, as agency directors have not issued explicit instructions by which these ethics counsellors should function - they have deprived them of any administrative rights upon which to off-set these liabilities.

\section{Figure 7: Obligations and Rights Created at Various Administrative Levels from the Code of Conduct Law}

\begin{tabular}{|l|l||l|}
\hline NACS staff & $\begin{array}{l}\text { Obligations } \\
\text { Major addition to obligations. The } \\
\text { NACS, in effect, becomes } \\
\text { responsible for all ethical breeches } \\
\text { in the Romanian administration. }\end{array}$ & $\begin{array}{l}\text { Countervailing rights established in the } \\
\text { Code of Conduct Law to demand } \\
\text { information and process cases of suspected } \\
\text { breaches of ethics. }\end{array}$ \\
\hline $\begin{array}{l}\text { Ethics Counsellors in } \\
\text { executive agencies }\end{array}$ & $\begin{array}{l}\text { These counsellors obliged to } \\
\text { control their ministry's staff and } \\
\text { act as liaison with the NACS. Yet, } \\
\text { they have no powers to subpoena } \\
\text { managers or suspects. }\end{array}$ & $\begin{array}{l}\text { None - these counsellors obtain no powers } \\
\text { to counsel staff, conduct preliminary } \\
\text { inquiries into ethics allegations, and do not } \\
\text { obtain more resources. }\end{array}$ \\
\hline $\begin{array}{l}\text { Ministerial and } \\
\text { executive agency } \\
\text { managers }\end{array}$ & $\begin{array}{l}\text { Managers have same obligations as } \\
\text { before to supervise staff - } \\
\text { obligation to send information to } \\
\text { NACS. }\end{array}$ & $\begin{array}{l}\text { None - managers can not 'pass off' liability } \\
\text { in the case of an ethics breach by their staff. }\end{array}$ \\
\hline $\begin{array}{l}\text { Cadre(s) of Civil } \\
\text { servants }\end{array}$ & $\begin{array}{l}\text { None - difficult to argue the Code } \\
\text { of Conduct Law imposes new } \\
\text { substantive rights or obligations on } \\
\text { the majority of Romanian civil } \\
\text { servants. }\end{array}$ & $\begin{array}{l}\text { None - the Code of Conduct Law does not } \\
\text { provide new protections or decreased } \\
\text { ambiguity during an administrative } \\
\text { proceeding in cases of suspected ethical } \\
\text { offences (under the Code of Conduct Law). }\end{array}$ \\
\hline
\end{tabular}

Source: authors.

Given the increased implicit obligations (and thus administrative liability) imposed on ethics counsellors, an administrative doctrine must establish either (preferably) secundum legem or (at the worst case) praeter legem rights for ethics counsellors. ${ }^{46}$ Under the present institutional design, agency directors hold liability for failing to provide the NACS with information (as required under article 20 of the Code of Conduct Law). Yet, no theory of administrative law would reasonably hold ethics counsellors liable for responsibility placed on them by their superiours if these superiours also did not delegate the authority required to fulfil those obligations. Part, if not most of that authority (or grant of administrative rights) consists of the right to counsel staff or engage in the prevention of ethical offences. Because agency directors are liable for counselling their staff on ethical issues, and because they have implicitly delegated this responsibility to ethics counsellors, ethics counsellors have the ad hoc right to engage in such training in order to reduce their own administrative liability for ethical faults in their department.

A doctrine of implied powers (related to the increased rights of ethics counsellors to deal with the obligations imposed on them) may be supposed on three grounds. First, Profs. Galligan and Smilov explicitly note that the Romanian executive has the authority to issue

\footnotetext{
${ }^{46}$ Secundum legem - more commonly known as secondary or delegation legislation - refers to regulations passed by executive agencies under the authority of parliament. Praeter legem refers to executive rulemaking without any explicit grant of authority by parliament. Praeter legem represents a fascinating area of law (as such law, at its best, represents executive initiative to respond to a changing regulatory environment). At its worst, praeter legem represents simple executive usurpion of parliamentary sovereignty.
} 
praeter legem as well as secundum legem (regulations). ${ }^{47}$ Such an administrative structure significantly simplifies the creation of a doctrine-based approach to administrative ethics. Second, without a functioning system of administrative courts, such praeter legem can not be challenged by the subjects of such rulemaking. Thus, the executive possesses de facto rights to engage in such policymaking - albeit with a narrow range allowed by parliament's failure to sanction the executive. Third, heads of executive agencies clearly intent to delegate their authority to these ethics counsellors, by virtue of creating these posts in the first place. The creation of an ethics counsellor job function, in itself, may be interpreted as a clear intent to delegate the minister's or director's authorities to his or her sub-ordinate otherwise, the move would be wasteful and irresponsible.

All Romanian agencies should adopt an executive instruction or regulatory instrument aimed at clarifying the many ambiguities inherent in these ethics counsellors' job functions. As shown above, the Code of Conduct Law -- and the act of creating ethics counsellors in the various Romanian government agencies -- clearly grants implied powers to these ethics counsellors. Many of these implied powers derive from praeter legem (de facto and unwritten rulemaking by the executive) associated with current work on civil servant ethics. Naturally, in a legal tradition which values predictability and clarity, executive agencies should prefer well-defined instructions and rules to the existing system of implied powers and informal obligations. Article 25 of the Code of Conduct Law clearly allows executive agencies to regulate in this area by, "harmoni[sing] their internal rules of organization and operation or the specific codes of conduct...[to the Code of Conduct Law].” The creation of a code of conduct regulation clearly comprises such "harmonisation."

\section{The Ethical Dilemmas of the Ethics Law and the Use of Legal Doctrine}

The Code of Conduct Law repeats and reflects ethical conflicts inherent in civil servants' work -- without providing any method of resolving them. Figure 8 shows some of the ethical dilemmas which clearly stand out in the Code of Conduct. Consider the following hypothetical scenario. A Romanian civil servant (let's call him Mircea) working in the Ministry of Finance knows a colleague with whom he studied in the USA. He knows his colleague (let's call him Alexander) would be the best candidate for a newly opened - and very important position (which involves working with Mircea). Mircea does not trust the current committee-based "objective" method of selecting candidates - as such committees tend to produce compromise candidates who are good at getting jobs and not so good at doing them. Mircea acts under the honest belief that his friend and colleague Alexander is the most qualified person for the job (and working with this individual would be much easier). On the one hand, the person should assist this person; as selecting a superiour candidate clearly represents the public interest (as required by article 5 of the Code of Conduct). On the other hand, the civil servant should clearly refrain from using personal relationships and helping friends (as required by article 12 of the Code of Conduct Law). In ethical dilemmas such as these, the Code of Conduct Law provides no guidance about how to select between its conflicting articles. The Code of Conduct Law makes some of the ethical dilemmas faced by Romanian civil servants clearer - but fails to provide any concrete method of resolving these dilemmas.

Romanian civil servants must be explicitly allowed to work out solutions - by forming legal doctrines -- to these ethical dilemmas. Romania's public administration - in its current incarnation - is relatively young. Romania's administrative law does not provide the same types of legal protections and a "case" history (for lack of a better word) of defending those

\footnotetext{
${ }^{47}$ See Denis Galligan and Daniel Smilov, Administrative LAW in CenTRAL AND EASTERN EuROPE, 19961998., 1999, p. 251.
} 
protections as the French, German or other Continental systems. ${ }^{48}$ In the French and Swedish systems (for example), the lowest level civil servants have discretion to take administrative decisions. Their decisions become part of the body of administrative, unless and until such time, as their superiours amend or veto those decisions. Romanian administrative law, though, does not explicitly allow for the delegation of administrative discretion to the lowest levels.

\section{Figure 8: Ethical Dilemmas Arising from Code of Conduct Law}

\begin{tabular}{|c|c|}
\hline Dilemma & Description \\
\hline $\begin{array}{l}\text { Public interest versus } \\
\text { Government interest } \\
\text { (art. } 5 \text { vs. art. 7) }\end{array}$ & $\begin{array}{l}\text { The government agency may take decisions which actually (or appear at the time) to } \\
\text { run counter to the public's interest. Examples include withholding information, or } \\
\text { bureaucrats engaging in seemingly wasteful activity in order to win internal } \\
\text { bureaucratic political games. Government agencies may also act in the long-term } \\
\text { public interest, ignoring present publicly popular policies. }\end{array}$ \\
\hline $\begin{array}{l}\text { Restraint on } \\
\text { relationships versus } \\
\text { need to provide high } \\
\text { quality services } \\
\text { (art. } 12 \text { vs. art. } 5 \text { ) }\end{array}$ & $\begin{array}{l}\text { Most notable when Romanian civil servants use personal friendships in order to } \\
\text { achieve work tasks (like calling in favours in order to get a delivery on-time). In } \\
\text { Romania, like in most public services, government contracts also follow the } \\
\text { invisible network of personal relations which "grease” the wheels of public sector } \\
\text { service provision. Such a conflict of interest also raises the possibility of corruption. }\end{array}$ \\
\hline $\begin{array}{l}\text { Freedom of expression } \\
\text { versus fidelity to } \\
\text { agency } \\
\text { (art. } 7 \text { vs. 8) }\end{array}$ & $\begin{array}{l}\text { Probably the most controversial (and ambiguous) part of the Code of Conduct Law). } \\
\text { The Law specifically prohibits civil servants from making public statements critical } \\
\text { of the government or the person's agency. However, such statements may serve } \\
\text { public interests as civil servants know the implementation of a policy at the ground } \\
\text { level. Such a conflict invokes the core value of freedom of speech versus the civil } \\
\text { servant's fiduciary responsibility to his agency. }\end{array}$ \\
\hline $\begin{array}{l}\text { Rule of law versus } \\
\text { efficiency } \\
\text { (art. } 5 \text { vs. } 6 \text { ) }\end{array}$ & $\begin{array}{l}\text { Should civil servants sit in offices writing reports which no one will read? On the } \\
\text { one hand, they have agreed (by their employment contract) to complete tasks given } \\
\text { to them. On the other hand, these reports seem to serve no purpose - so the civil } \\
\text { servant should "run away" (to the extent possible) from these wasteful assignments. }\end{array}$ \\
\hline $\begin{array}{l}\text { Conflict of interest } \\
\text { (art. } 9 \text { vs. 12). }\end{array}$ & $\begin{array}{l}\text { In theory, when the civil servant serves his own interests, he or she serves the public } \\
\text { interest (as long as his or her incentives are aligned with the interests of the public). } \\
\text { An example of a potential ethical dilemma arises from a government officials work } \\
\text { in an NGO which works on a topic directly related to his agency's work. On the one } \\
\text { hand, the government official would have a great deal of expertise to offer the NGO. } \\
\text { On the other hand, the government official may be tempted to use his influence to } \\
\text { affect the NGO's (or his agency's) policy. }\end{array}$ \\
\hline
\end{tabular}

source: authors

As other European countries' administrative legal systems show, a doctrinal approach toward ethics regulation is not antithetical to the civil law system. France's deontological approach to ethics (or the systems used all over the EU) whereby ethical decisions are challenged in administrative tribunals or courts, provides a type of "case law" by which civil servants establish (at their own risk) ethics-related doctrines. ${ }^{49}$ The Romanian civil servant certainly possesses the authority - by virtue of the prateur legem and the implied powers conferred by the Code of Conduct Law - to establish particular doctrines related to civil servant ethics.

In most civil law jurisdictions, ethic- related legal doctrines - and the doctrinal approach to ethics regulation which we advocate in this paper - evolved roughly as shown in Figure 9. Civil servants in these jurisdictions, exposed to the numerous ethical dilemmas of their daily

\footnotetext{
${ }^{48}$ Dr. Bobek provides an interesting discussion of the evolution of reasonableness as a test of administrative action in a number of European jurisdictions. See Michal Bobek, Reasonableness in Administrative Law: A Comparative Reflection on Functional Equivalence, in Giovanni Sartor, Giorgio Bongiovanni, and Chiara Valentini, REASONABLENESS AND LAW, 2009.

${ }^{49}$ A comparison of European administrative legal systems would take our discussion outside the bounds of a relatively short paper. As such, we refer the reader to the authors we cite for a fuller description.
} 
work, took discretionary decisions - often with the knowledge of relevant hard law provisions, such as not discriminating between service users based on ethnicity or gender. ${ }^{50}$ Recently, as shown in Figures 3 above, these civil servants will have received codes of conduct or similar ethical guidance in the form of soft law. Civil servants with discretionary authority take discretionary decisions (on situations involving an ethical dilemma) based on some system of values - often personal values. ${ }^{51}$ In written form, these decisions form the basis of formal ethics-related administrative law. Unwritten decisions, while not representing precedents in the formal sense of Anglo-Saxon law, do create expectations by service users (and other civil servants who observe the decision being taken) in the future. ${ }^{52}$ In most civil law jurisdictions, failure to decide similarly in similar circumstances would constitute capricious and arbitrary behaviour -- which would be stricken down in administration fora (such as by the agency's director or an administrative court where available) or in political fora (such as appearing in the daily newspaper and exposing the ministry to political pressure to apply consistent rules). The codification of government ethics, in a civil law system (such as Romania), proceeds much more on a doctrinal approach than other parts of administrative law. Decisions taken by civil servants - and the various forms of soft law previously mentioned -- form a legitimate expectation by both service uses and other civil servants than such ethics-related decisions shall be repeated in similar circumstances. Challenges to these decisions require written replies from either the head of the agency or an administrative court - formalising previously informal parts of ethics-related administrative law.

\section{Figure 9: The Development of Legal Doctrines Guiding Administrative Law in Cases of Potential Breaches of Civil Servants' Ethical Conduct}

1. Consider facts of the ethical dilemma and any relevant hard or soft law provisions

2. Take a decision based on post-conventional or deontological principles

3. Wait for challenge by either subject of ethical decision or supervisor

4. If no challenge, decision forms part of legitimate expectation by both service users and other civil servants (though no stare decisis or binding precedent),

5. If challenged, the administrative supervisor (or administrative court if existing) takes a decision usually issuing an administrative decision (again, no stare decisis in civil law jurisdictions), 6. Resolutions of these ethical dilemmas form informal institutions (through administrative enculturation) and formal institutions (through subsequent administrative decrees and formal decisions).

Source: authors.

\footnotetext{
${ }^{50}$ Many Central and Eastern European countries are only starting to develop a well categorised body of administrative law. In these countries, hard (or soft) law provisions related to ethics would be found in director's instructions or decisions (such as emails to all staff or instructions duly stamped and sent around to all staff by paper post). The filing and categorisation of these emails in something like a consolidated code of regulations or procedures is almost entirely lacking. The relative chaos by which administrative acts are promulgated further militates for a doctrine-based approach to ethics-related regulation. Civil servants require overarching principles which can be easily remembered instead of specific instructions contained on various scraps of paper which may be lost in the office.

${ }^{51}$ Most of the empirical studies previously cited show that civil servants resolve ethical dilemmas according to the ethical values they receive at home or their personal values -- and not according to any system of administrative values. Professor Gibson notes that most administers in the US still use "conventional” moral reasoning instead of the preferred post-conventional. See Pamela Gibson, Examining the Moral Reasoning of the Ethics Adviser and Counselor: The Case of the Federal Designated Agency Ethics Official, 11 PuB. INTEGRITY 2, 2009. Any discussion of these frameworks would take us outside of the bounds of the present paper.

${ }^{52}$ In the Anglo-Saxon legal tradition, the doctrine of legitimate expectation covers roughly these ideas. The codified civil law tradition requires less such a doctrine, as the principles of consistency and predictability govern the codification and application of civil law.
} 
The potential for the inconsistent application of ethics-related doctrine seems to violate the fundamental nature of the rule of law which a civil law tradition upholds. However, ethical decisions occur in the area of law where no consensus already exists on a course of action otherwise, hard law (rather than soft law) would guide civil servants. The inconsistent application of ethics doctrine then already occurs. Moreover, there is no a priori reason to think that one single doctrine should govern different ministries in the public sector. A popular view of ethics in executive agencies views Ministry of Health officials placing compassion as an important ethical value. Whereas such popular notions of administrative ethics might see officials in the Ministry of Finance esteeming hard-nosed, efficiency oriented decisions. Civil servants in the Ministry of Culture can be (and should be) more "liberal" than those in the Ministry of Defence. ${ }^{53}$ The Ministry of Health (or Culture) attracts different types of applicants --with different ethical values -- than the Ministry of Finance (or Defence). Multiple ethical doctrines can (and do) operate in different public sector organisational units. The development of different these different ethical doctrines in Romania would result in a rich administrative case law, adjudicated by administrative law judges and senior level officials who can steer decisions toward a consensus. Their decisions - which remove doctrines which do not conform to some basic understanding of ethics held by the majority of civil servants - can form the basis of a broader public sector ethics doctrine. $^{54}$

Indeed, to resolve these ethical dilemmas, the Romanian civil service must allow for a doctrinal approach to the creation of ethics-related administrative law. Romanian agencies will not allow the NACS to engage in extensive regulation over their internal affairs. At first glance, the NACS adopting an ethics regulation covering all government agencies seems to comprise the fastest and easiest approach to establishing a unitary framework of ethicsrelated administrative law in Romania. ${ }^{55}$ Yet, even the low rates of compliance with the current Code of Conduct Law - requiring all agencies to submit ethics related information required by the Ethics Order to the NACS -- suggests that Romanian government agencies will not simply yield to the NACS's will. ${ }^{56}$

Other reasons militate for a doctrinal approach to ethics-related administrative law in Romania. A doctrinal approach to administrative ethics can provide the new ethics counsellors in Romanian public agencies with a useful role. Literally, thousands of civil servants - serving as the ethics counsellors for their agencies - are sitting around waiting for direction. Moreover, the application of a doctrinal approach to administrative ethics can help overcome the wide-spread administrative inertia which follows from excessive civil servants' risk-averse. ${ }^{57}$ In other civil law jurisdictions, civil servants balance the risk and

\footnotetext{
${ }^{53}$ In the last 5 years, a number of researchers have attempted to quantify (using surveys) these differences in values. For one example of such a survey, see Vrangbaek, Karsten, Public Sector Values in Denmark: A Survey Analysis, 32 INT’L J. PuB. AdMin.6, 2009.

${ }^{54}$ Such an approach represents the standard method by which ethics-related legal doctrines are made in civil law jurisdictions.

${ }^{55}$ The Civil Service Law empowers the NACS to create regulating binding on the whole Romanian civil service.

${ }^{56}$ Data for exact compliance are difficult to obtain. However, anecdotal evidence suggests a very low level of compliance.

${ }^{57}$ The literature on the Romanian civil service widely comments on this risk aversion (and simple inertia). Iancu and Ungureanu, besides presenting data showing the extent of this phenomenon, note that such risk aversion arises as the result of rational strategic actions by these civil servants. In a rather cunning argument, they claim that a highly politicised civil service exposes civil servants to professional risks and an everchanging policy environment. By strictly following department procedures and not doing extra work which could expose them to reprisals of other staff, they manage to remain employed without facing these reprisals.
} 
return of their ethical decisions - often placing themselves at risk (and receiving rewards for taking those risks). These civil servants act - because their administrative law indemnifies them in cases where their risk-taking (in the public interest) has unforseen, negative consequences. Forcing Romanian civil servants to act, based on a particular doctrine of administrative ethics - and forcing them (rather than their superiours to answer for their decisions) - teaches them to take acceptable risks in the public's interests much more than any training course. As such, the interesting legal question revolves not on whether a doctrinal approach to ethics is allowed, but how regulatory instruments can implement such an approach legally.

An implementing regulation for the Code of Conduct Law - adopted by line ministries would improve the effectiveness of the Law. As shown in Figure 8, the Code of Conduct Law itself contains ethical tensions which only a set of principles can resolve. ${ }^{58}$ As subsequently shown in Figure 9, in the administrative law of many civil law jurisdictions, the decisions taken by civil servants, ethics counsellors and agency managers (decisions which resolve these ethical dilemmas) become codified into procedures and a more formal body of administrative regulation. A regulation, clarifying the ways in which government agencies can apply the Code of Conduct Law provides procedural rights which civil servants may subsequently rely upon if their discretionary decisions are later challenged. ${ }^{59}$ An ethics regulation - defining the ways by which ethics doctrines can be defined given the legislation in force - would ensure procedural (if not substantive) consistency and the rule of law.

An implementing regulation for the Code of Conduct Law, most importantly, would provide the basis of a single, consolidated piece of law - helping to unify the various provisions contained in the multiple ethics-related legislative acts. As Prof. Mungiu-Pippidi notes, "too many pieces of legislation compete and overlap already on corruption and accountability. The main piece addressing civil servants is far from being comprehensive, nor does it cover their possibly being related to a controversial activity before or after having a public position, and carries no penalties for infringement...The administration needs one clear code of conduct." ${ }^{60}$ An implementing regulation, at the administrative level, can provide that clear code of conduct.

\section{The Current Legal Framework Governing Civil Servant Ethics}

In Romania, like in most other countries, legislative provisions related to civil servant ethics comprises more than just the items in the Code of Conduct Law. Most importantly, the Romanian parliament has also adopted laws on the disclosure of assets and the conflict of interests under the Law on the National Integrity Agency. ${ }^{61}$ The National Integrity Agency Law provides that mostly senior officials shall submit asset declarations and conflict of

See Diana-Camelia Iancu and Mihai Ungureanu A Public Choice approach to the selection of bureaucrats in Romania, available online.

${ }^{58}$ Figure 12 below describes some of the specific tests civil servants can use to resolve these tensions inherent in the Code of Conduct law.

${ }^{59}$ The creation of clear administrative procedures governing the way by which civil servants can take discretionary ethics-related decisions (based on doctrines developed in their administrative legal framework) would also help reduce their aversion taking the risks concomitant with those decisions. Even if Romanian civil servants took the "wrong" decision - but using the "right" procedure - they could rely on their following the procedures in their defence.

${ }^{60}$ Alina Mungiu-Pippidi, Corruption or Widespread Administrative Malfunction - A Policy Failure Warning, paper presented at the conference Informal Economy in the EU Accession Countries: Size, Scope, and the Trends in Trafficking and Corruption, Sofia, available online.

Corruption or Widespread Administrative Malfunction - A Policy Failure Warning

${ }^{61}$ National Integrity Agency Law (No. 144/2007) as modified by Government Emergency Ordinance 49/2007, [hereinafter the National Integrity Agency Law]. 
interest declarations - though subsequent laws have expanded the requirement to civil servants. ${ }^{62}$ The Law requires all public officials to submit both asset declarations and conflict of interest statements annually. ${ }^{63}$ The National Integrity Agency ensures that public officials submit declarations on-time and provides ongoing verification of the data in the declarations. ${ }^{64}$

While the Code of Conduct Law appears to cover the soft law parts of Romania's government ethics legal framework, the National Integrity Agency Law clearly contains the hard law provisions. Figure 10 compares the rigidity of the National Integrity Agency Law's provisions with the provisions contained in the Code of Conduct Law. ${ }^{65}$ Such rigidity the extent to which each article creates substantive rights or obligations which can be independently assessed and relied upon. For example, article 7.1 of the Code of Conduct Law requires loyalty to public authorities -- specifically establishing that they shall "protect the prestige" of their institution as well as "refrain from any action that might harm its image or its legal interest." Without a more specific test - establishing a legal definition for prestige (for example), a Romanian public official can not know whether his statements maybe even critiques of the agency's policy - hurt the agency's prestige or bolstered it. ${ }^{66}$ Without more specific provisions (or a regulatory instrument defining the conditions under which public statements materially damage an agency's prestige), an administrative court would have a very little guide for determining if the public official acted appropriately.

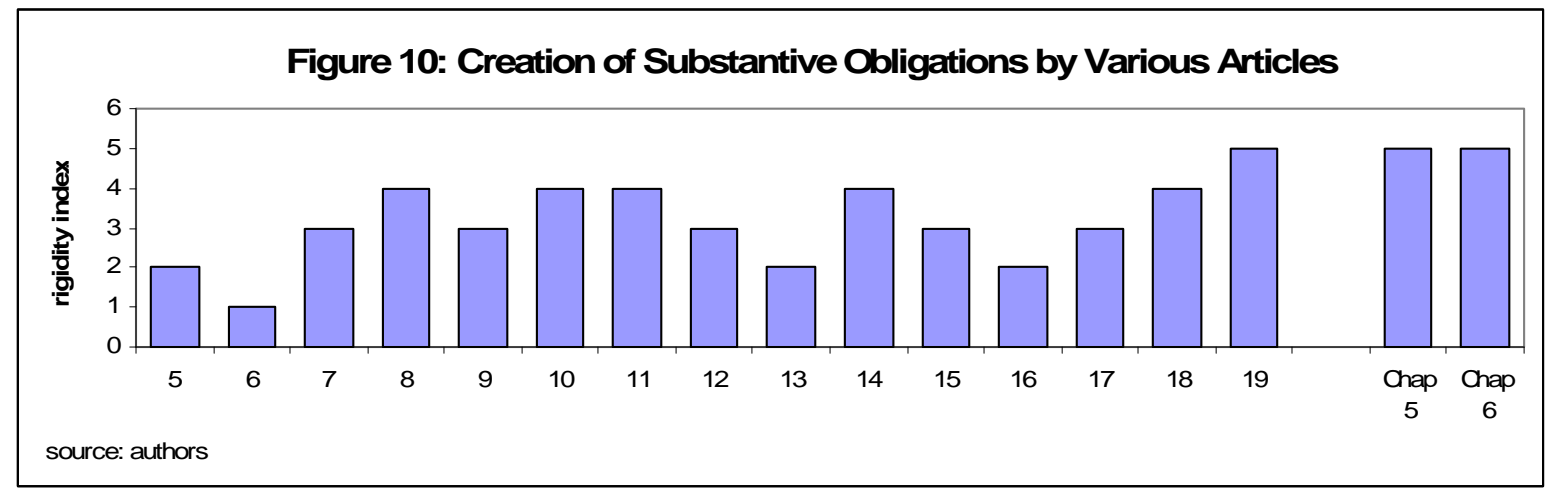

In contrast, the National Integrity Agency Law represents the hard law part of Romania's ethics law. For example, article 4 - relating to the preliminary verification of declarations Agency inspectors receive -- contains 9 sub-provisions outlining the exact procedures to use. The article, like most in the Law, outline the time period for verification (art. 4.1), the

\footnotetext{
${ }^{62} \mathrm{Id}$. at art 9. Art. 9.2h specifically allows for other persons to submit these declarations "as provided by law." Such phrasing is usually meant as provided by other acts, regulations and other legal decisions. Confusingly, the same law subsequently - in article 39 - provides a more exhaustive (34 point) list of persons who should submit these declarations. Specifically, 39.1(29) mandates the submission of such declarations by "persons with leading and control positions" and "public servants, including those with a special status." The sub-point clearly aims to cast the net as wide as possible - covering those "who carry out their activity within all the central or local public authorities or, as the case may be, within all public institutions."

${ }^{63}$ Id. at art $42(2)$.

${ }^{64}$ Id. at art 13

${ }^{65}$ As noted in Figure 4, the rigidity of legal provisions relates to the extent by which they create definite substantive rights or obligations which can be independently assessed (by an administrative court for example) for compliance.

${ }^{66}$ During the 1990s, many Western civil servants to offer carefully constructed critical assessments of their agencies' policies. Such assessments allowed them to show the public that government officials could be selfcritical and did not suffer from "bunker mentality" as claimed in many newspaper articles. Many writers have described the process by which media coverage affects ministerial work and the delivery of public services. For a standard reference about the mediatization of public sector work of For a standard reference in this area, see T. Cook, Governing With the News: The News Media AS A Political Institution, 1998.
} 
procedure to follow (art. 4.2), procedures to follow in case the Agency finds an inaccurate declaration (art. 4.3), a definition of material mis-statements (art. 4.4), the duty to notify authorities in cases when the Agency detects material mis-statements (arts. 4.5 and 4.6), release of persons from inspection (art. 4.7), provisions protecting the confidentiality of declarations (art 4.8), and a clause guaranteeing immunity if person being audited is not informed about the Agency's inspection (art. 4.9).

These provisions - as well as others -- represent Romania's ethics-related legal framework. An ethics related legal framework is defined as the soft law and hard law provisions, specifically defined under a government ethics programme or policy, and found in various legislative and regulatory acts which aim to regulate public official's conduct. As shown in Figure 11, the Romanian ethics legal framework consists of a number of legislative acts which impose obligations on public officials. ${ }^{67}$

Figure 11: Romania's Ethics Legal Framework Legislatively Implied Obligations on Ethics Counsellors

\begin{tabular}{|l|l|}
\hline Law & Implied Responsibilities on Ethics Counsellors \\
\hline Code of Conduct Law & $\begin{array}{l}\text { Most directly establishes basis for work of ethics counsellors (and civil } \\
\text { servants). }\end{array}$ \\
\hline Anti-Corruption Law (78/2000) & To advice in cases where civil servants either take bribes or are solicited. \\
\hline Civil Service Law (188/1999). & $\begin{array}{l}\text { Imposes many of the same obligations on civil servants, but now ethics } \\
\text { counsellors are obliged to monitor compliance (particularly arts. } \\
\text { 40somethings). }\end{array}$ \\
\hline $\begin{array}{l}\text { Asset Declaration Law } \\
(115 / 1996)\end{array}$ & $\begin{array}{l}\text { give advice on compliance with asset declarations, cover ethical } \\
\text { dimensions (how to value assets, what constitute a conflict of interest and } \\
\text { so forth). }\end{array}$ \\
\hline $\begin{array}{l}\text { Law on Transparency } \\
(161 / 2003)\end{array}$ & $\begin{array}{l}\text { Ethics counsellors can advice what to publish online, how to deal with } \\
\text { requests for information which are in the public interest (but not the } \\
\text { Agency's interest or the interests of its minister). }\end{array}$ \\
\hline $\begin{array}{l}\text { Whistleblowers Law } \\
\text { (571/2004) }\end{array}$ & \begin{tabular}{l} 
Give advice on whether to blow whistle, provide advice on how to blow. \\
\hline
\end{tabular}
\end{tabular}

Source: authors.

An implementing regulation can resolve the ambiguity arising from the current ethicsrelated legal framework. For example, the Whistleblowers Law's definition of the public interest directly clashes with the definition provided by the Code of Conduct Law. In the Code of Conduct Law, the emphasis placed on the "public interest" stresses the public as "natural and legal persons, of public and private law, Romanian and foreign" with a side emphasis on "[as well as] the fulfilment of duties by public servants." ${ }^{6}$ In contrast, the Whistleblowers Law stresses "the integrity, impartiality and efficiency of public authorities and institutions" as comprising the public interest. ${ }^{69}$ The Whistleblowers Law goes on to attempt to establish its own supremacy over the Code of Conduct Law; through article 4d which notes that "in case of public interest warning the deontological or professional norms which might prevent the public interest warning shall not be enforceable.” Clearly, if

\footnotetext{
${ }^{67}$ Other laws include Law No. 215/2001 on Local Public Administration (including various amendments), Law on Local Public Administration (2001). For a more complete description of this legal framework, see Adrian Moraru, Adrian Baboi-Stroe, Adrian Badila, and Corneliu Liviu Popescu, New Ways of Managing Conflict of Interest Problems in Romania, In Barbara Kudrycka, COMBATING CONFLICT OF INTEREST IN LOCAL GovernmentS IN THE CEE COUNTRIES, 2004. See also, Leo Huberts, Jeroen Maesschalck and Carole Jurkiewicz, Ethics AND InTEgRITY OF GOVERnANCE: PERSPECTIVES ACROSS Frontiers, 2008. Figure 10 provides the Romanian ethics legal framework.

${ }^{68}$ Code of Conduct Law, art. 4b.

${ }^{69}$ Whistleblowers Law, article $4 \mathrm{~b}$
} 
parliament is unwilling or unable to explain when these various provisions come into force, interpretation must be done at the regulatory level.

\section{An Implementing Regulation for Romania's Code of Conduct Law}

The adoption of an implementing regulation would add clarity and predictability to the present legal framework governing public officials' ethics. ${ }^{70}$ An implementing regulation would help clarify ambiguous substantive rights and obligations. As previously shown in the examples of the conflicting articles $4 \mathrm{~b}$ between the Code of Conduct Law and the Whistleblowers Law, an implementing regulation would define the methods by which civil servants could establish legal doctrines in order to resolve substantive ambiguities. An implementing regulation would also define clearly defined procedural rights which Romanian civil servants can rely upon in cases of administrative disputes or litigation. As previously discussed, Romanian civil servants already define ad hoc ethical doctrines (albeit without the explicit sanction or guidance from parliament). Implicitly, however, Romanian civil servants have - at least in theory -- implied powers to engage in such rulemaking (emanating from the Code of Conduct Law). A clear procedure would help ensure these decisions are recorded and consulted in the future.

Given the present evolution of Romanian jurisprudence in this area, ethics counsellors rather than working level civil servants -- form the subjects of such regulation. Ethics counsellors, not civil servants, received delegated competencies from their director and from the NACS. Ethics counsellors, and not working level civil servants, become specialists in the Romanian ethics-related legal framework. Ethics counsellors, not working level civil servants, face greater legal obligations from the present legal framework - and greater liability in case these obligations are not fulfilled. Rights over regulating on ethics issues should be assigned to government officials who possess the greatest experience dealing with day-to-day ethical issues. ${ }^{71}$ Thus, ethics counsellors should be the main subjects regulated by second rulemaking which implements the Code of Conduct Law (and other legislative instruments related to Romania’s ethics-related legal framework).

\section{Provisions Enabling the Creation of Ethics-Related Administrative Doctrines}

A regulation should formalise the already existing right (and obligation) of agency-level ethics counsellors to provide ethics-related counselling to staff. Such counselling should also include the competence to serve as a mediator in cases where the solution to an ethical dilemma between work colleagues differs. Such counselling would be particularly important for cases involving whistleblowing (when one civil servant wants to denounce the seemingly unethical behaviour of another). However, in the course of such advice-giving, the ethics counsellor still runs into the real, ambiguous clash of values inherent in any ethical dilemma (which as Figure 8 showed, the Code of Conduct Law fails to resolve).

A regulation which implements the Code of Conduct Law should define a series of doctrinal tests in order to guide the ethics counsellors' advice. Figure 12 shows the types of doctrines (as derived from the authority granted in the Code of Conduct Law and other legislation

\footnotetext{
${ }^{70}$ An ethics-related legal framework, as previously defined, comprises the soft law and hard law provisions, specifically defined under a government ethics programme or policy, and found in various legislative and regulatory acts which aim to regulate public official's conduct.

${ }^{71}$ In the language of new institutional economics, property rights over regulatory decisions (with specific regard in this case to ethics regulations) should be assigned to civil servants to obtain the greatest residual benefits. As previously noted, ethics counsellors are most inconvenienced by the present legislative set-up. Thus, they should have the right to regulate in order to maximise the scheme's overall social benefits. See Eirik Furubotn and Rudolf Richter, InSTITUTIONS AND ECONOMIC THEORY: THE CONTRIBUTION OF THE NEW INSTITUTIONAL ECONOMICS, 2005.
} 
cited in the figure) which Romanian civil servants could rely up - if such a regulatory instrument were adopted - while making difficult ethical decisions. For example, the ethics counsellor - giving advice on a case of possible nepotism - could apply an efficiency test. Such a test basically weighs whether the better use of resources justifies the social harms inherent helping a relative or close friend (who would be a better "fit" for the assignment even though he is unlikely to be selected by a committee) gain employment in a government agency. Such questions can not be answered a priori - as the length of time employed, the nature of possible competition and other factors all determine the relative costs and benefits of allowing such "discriminatory” practices to succeed. In ethical dilemmas such as these, the public official's discretion - guided by the ethics-related doctrines advocated and adopted by their agency’s ethics counsellors - serves an important purpose. ${ }^{72}$

\section{Figure 12: Doctrinal Tests for Establishing Compliance with Code of Conduct Law}

\begin{tabular}{|c|c|}
\hline Test & Description \\
\hline $\begin{array}{l}\text { Efficiency Test } \\
\text { (allowed under art. } \\
\text { 4(e) of the } \\
\text { Whistleblower's Law) }\end{array}$ & $\begin{array}{l}\text { Establish a three-part disjunctive test for determining which of several possible } \\
\text { courses of action result in the same outcome with fewer resources (staff time, budget, } \\
\text { etc.), or cost more in the short-term in activities which result in long-term saving of } \\
\text { resources (such as staff time, government funds, etc.), or result in a higher risk- } \\
\text { adjusted return - namely result in the same outcome with a lower risk, even if more } \\
\text { resources must be used in order to guarantee these reduced risks. }\end{array}$ \\
\hline $\begin{array}{l}\text { Effectiveness Test } \\
\text { (allowed under art. } \\
4(\mathrm{e}) \text { of the } \\
\text { Whistleblower's Law } \\
\text { and art. } 5 \text { of the Code } \\
\text { of Conduct Law) }\end{array}$ & $\begin{array}{l}\text { Establish a three-part disjunctive test for determining which of several possible } \\
\text { courses of action result in the better outcome with the same or fewer resources (staff } \\
\text { time, budget, etc.), or prefer activities which cost more in the short-term in activities } \\
\text { which result in long-term benefits to the public (such as staff time, government } \\
\text { funds, etc.), or suppress any activity which does not directly serve the public interest } \\
\text { (following rules only for the sake of following rules). }\end{array}$ \\
\hline $\begin{array}{l}\text { Golden Mean Test } \\
\text { (Code of Conduct } \\
\text { Law, arts 3e and 3f) }\end{array}$ & $\begin{array}{l}\text { In cases where the public interest comes into conflict with the rule of law, the ethics } \\
\text { counsellor shall work with the advisee to find a solution which both upholds the } \\
\text { public interest without violating legal procedures. In cases where the Ethics } \\
\text { Counsellor and Advisee can not find such a solution, the ethics counsellor should } \\
\text { seek competent legal advice. }\end{array}$ \\
\hline $\begin{array}{l}\text { Proportionality Test } \\
\text { (article 4(d) of the } \\
\text { Whistleblower's Law) }\end{array}$ & $\begin{array}{l}\text { In cases where a whistleblower or public official wants to "take justice into his own } \\
\text { hands" (but attempting to thwart the action of another), the ethics Counsellor } \\
\text { provides an advisee advice on possible second-best measures (as stopping the person } \\
\text { probably represents the best option). Ethics counsellor advice ensure these second } \\
\text { best measures: a) do not cost more (or inflict more harm) then the harm the public } \\
\text { official is trying to prevent, b) that the action corresponds with actions taken by other } \\
\text { public officials in similar circumstances and c) would not be poorly seen if leaked to } \\
\text { the press. }\end{array}$ \\
\hline
\end{tabular}

\footnotetext{
${ }^{72}$ Many commentators would argue against giving Romanian ethics counsellors (and the public officials they advise) discretion in areas such as the case of potential nepotism we provide. They argue for extremely clear and strict "bright lines" and prohibitions - particularly given the risk of corruption inherent in the use of such discretion. Simple restrictions however can suppress the ethical dilemma - making the final decisions taken by these public officials less just. Prohibitions on public officials' use of discretion to make ethics-related judgments may be compared to prohibitions on owning knives because owners may use these knives to kill someone. Clearly, the legal response to such a risk is to regulate the purchase, use and disposal of knives and not to establish an out-right prohibition (otherwise, society forgoes a large number of cooked meals). For a useful, though dated paper, covering these issues, see Robert Seidman, Drafting for the Rule of Law: Maintaining Legality in Developing Countries, 12 YALE J. INT'L L. 84, 1987.
} 


\section{Figure 12 continued: Doctrinal Tests for Establishing Compliance with Code of Conduct Law}

\begin{tabular}{|l|l|}
\hline $\begin{array}{l}\text { Principle of } \\
\text { Responsibility } \\
\text { (clarifying art. 4(c) of } \\
\text { the Whistleblower's } \\
\text { Law) }\end{array}$ & $\begin{array}{l}\text { Used in determining whether an ethics counsellors should accept denouncements or } \\
\text { advice in cases in which a whistleblower or advisee does not possess evidence to } \\
\text { support his or her allegation. Ethics counsellors can use a five-part list test such that } \\
\text { the denouncement: a) can not be used as proof or testimony in disciplinary or other } \\
\text { proceedings, b) helps establish the credibility of the concerned party (the accused), } \\
\text { provides intelligence which may be useful in further investigation(s), the ethics } \\
\text { counsellor assigns a credibility rating of the advisee (whistleblower) making the } \\
\text { denouncement and/or e) the warning allows the ethics counsellor to draw conclusions } \\
\text { about the Agency's policy environment (or incentives provides to civil servants } \\
\text { generally) - seeing the concerned party as only responding to general policy signals. }\end{array}$ \\
\hline $\begin{array}{l}\text { Good Faith Test } \\
\text { (clarifying art. 7.1(a) } \\
\text { of the Whistleblower's } \\
\text { Law) }\end{array}$ & $\begin{array}{l}\text { contrary.” However, the law does not provide a definition for such good faith. A } \\
\text { four-part disjunctive test could be applied establishing whether the whistleblower had } \\
\text { evidence, whether the person made a reasonable attempt to confirm those facts, } \\
\text { whether a common person would arrive at the same conclusion and whether the risk } \\
\text { or potential damage significant enough to warrant action. }\end{array}$ \\
\hline $\begin{array}{l}\text { Balancing Test for } \\
\text { equality versus the } \\
\text { public interest }\end{array}$ & $\begin{array}{l}\text { In cases or consultations where the advisee's circumstances (membership in ethic } \\
\text { group, geographical grouping, etc.) warrant special consideration, the ethics } \\
\text { counsellor shall seek legal advice to ensure that such advice is non-discriminatory. } \\
\text { Such an undaring doctrine ensures the most conservative application of the law. }\end{array}$ \\
\hline
\end{tabular}

Source: authors.

Such an ethics regulation would need to define mechanisms whereby ethics counsellors' codify their decisions into ethics-related legal doctrines over time. As previously noted, only ethics counsellors should be allowed to create ethics related legal doctrine - as they have the experience and specialisation in this area. In a set of circulars (much like lawyers, accountants and auditors use), ethics counsellors can post recent interesting cases (leaving out people's names). Other ethics counsellors can consult these decisions when taking their own decisions. The advice contained in these circulars does not comprise legal precedents as the circulars have no legal authority. However, as ethics counsellors may use whatever reasoning the think will stand up (will be seen as just by the involved parties and succeed during any appeal to a superior official or administrative court). Ethics counsellors decisions comprise (a part of) Romanian administrative law by virtue of the authority granted to them by their minister/director and the Code of Conduct Law. Such a system of circulars has the added benefit that doctrines contained in them can be debated in the College of Ethics Counsellors (see below).

While ethics counsellors should offer advice (comprising soft law), they should also have the recourse to hard law administrative remedies in order to give force to the ethics-related legal framework. Namely, in particular circumstances, ethics counsellors should be able to stop unethical behaviour for occurring (or mandate that public officials in their agency take decisions conforming to the agency's ethical doctrines). ${ }^{73}$ Such administrative orders coming on ethics counsellors on the authority of the agency's minister or director - should safeguard the legal and financial interests of the agency. Orders requiring a public officials recusal (in a situation of a possible conflict of interest) or the return of a gift comprise obvious examples of the useful application of such administrative powers. Figure 13 provides an overview of possible orders which ministers of agency directors should reasonably divest to their ethics counsellors.

\footnotetext{
${ }^{73}$ Authority for such decisions clearly derives from the agency Director or Minister (being implicitly or explicitly delegated as a necessary function of the ethics counsellor in protecting the directors (or ministers) fiduciary interests.
} 
Figure 13: Administrative Orders from Ethics Counsellors

\begin{tabular}{|c|c|}
\hline Order & Rationale \\
\hline $\begin{array}{l}\text { Order requiring the publication } \\
\text { (or withholding) of information } \\
\text { required by arts. 5.2, } 7.2 \text { and } 8.1 \\
\text { of the Code of Conduct Law }\end{array}$ & $\begin{array}{l}\text { The law requires Romanian government agencies to uphold the principle } \\
\text { of transparency and openness. However, the law also requires statements } \\
\text { not to harm the agency's interest. Asking the agency director for } \\
\text { permission for each relevant case results in bottlenecks (and civil servants } \\
\text { giving up trying to share information with the public). Ethics counsellors } \\
\text { should have the delegated authority to issue orders based on the } \\
\text { minister's or director's policy preferences. }\end{array}$ \\
\hline $\begin{array}{l}\text { Issue injunctions against } \\
\text { particular types of workplace } \\
\text { conduct (such as participating in } \\
\text { political activities and so forth). } \\
\text { required by art. } 10 \text { of the Code of } \\
\text { Conduct Law }\end{array}$ & $\begin{array}{l}\text { The ethics counsellors should not act as a spy or hall monitor. However, } \\
\text { if the ethics counsellors sees flagrant violations of the law, his or she } \\
\text { should be able to order civil servants to stop such behaviour without } \\
\text { going to the head of the agency. Such injunctions have the same legal } \\
\text { force as direct decrees from the agency’s head (and expose the civil } \\
\text { servant to the same disciplinary responsibility for non-compliance). }\end{array}$ \\
\hline $\begin{array}{l}\text { Indemnify civil servants who } \\
\text { take risks in fulfilment of the } \\
\text { Code of Conduct Law's } \\
\text { principles } \\
\text { art } 5 \text { of the Code of Conduct Law }\end{array}$ & $\begin{array}{l}\text { An request to a superiour official asking for permissions serves as an } \\
\text { insurance policy...and indemnifies the civil servant in case the decisions } \\
\text { results in any harm. Such extreme risk aversion results in the } \\
\text { centralisation of administrative decision taking by the agency's senior } \\
\text { management. Ethics counsellors can provide support - in the form of } \\
\text { written opinions - to civil servants wishing to "do the right thing” in a } \\
\text { morass of bureaucratic encumbrances. }\end{array}$ \\
\hline $\begin{array}{l}\text { Order Implementing NACS's } \\
\text { findings } \\
\text { art. } 22 \text { of the Code of Conduct } \\
\text { Law }\end{array}$ & $\begin{array}{l}\text { The Code of Conduct Law requires the NACS to communicate its } \\
\text { recommended punishments (or resolutions to cases involving ethical } \\
\text { dilemmas) to the agency involved. The ethics counsellor should receive } \\
\text { these reports and implement them (on the authority of the head of the } \\
\text { agency). The ethics counsellor should have the discretion to modify the } \\
\text { judgment or defend the accused (if such a defence is warranted). }\end{array}$ \\
\hline $\begin{array}{l}\text { Order to fill in conflict of } \\
\text { interest declaration } \\
\text { art. } 9.1 \text { of the National Integrity } \\
\text { Agency Law }\end{array}$ & $\begin{array}{l}\text { The National Integrity Agency Law requires Romanian government } \\
\text { agencies to appoint an official to ensure the collection of asset and } \\
\text { conflict of interest statements. The ethics counsellor can advice on filling } \\
\text { in these forms (what constitutes a conflict of interest under the law, how } \\
\text { to value assets and so forth). }\end{array}$ \\
\hline
\end{tabular}

Source: authors.

While such competencies can be bestowed to ethics counsellors at the agency-level, Romanian administrative should develop a general system of ethics counsellor authority across the entire public sector. The NACS (according to the Code of Conduct Law) possesses the competence for regulating and supervising civil servant ethics - as well as coordinating ethics-related policy across institutions. ${ }^{74}$ Yet, only ministers and agency directors can delegate the authority to implement ethics programmes in their own agencies. The NACS can not require for example that ethics counsellors in the Ministry of Finance conduct spot-checks to ensure that particular members of staff are not involved in a situation leading to a conflict of interest. Yet, different heads of agencies and ministers endow different competencies to their ethics counsellors. Some heads of agencies may take a more or less lenient approach toward the use of ethics counsellors’ powers (as previously discussed public officials in different agencies are likely to have different ethical values). Ethics counsellors themselves may have very different approaches to ethics-related doctrine. A system of administrative law must arise to cover the actions of these ethics counsellors. The current legislation does not establish a unified base upon which to endow ethics counsellors with administrative rights. However, such a system must be arrived at by

\footnotetext{
${ }^{74}$ Article 20.1 of the Code of Conduct Law specifically notes that “the National Civil Servants' Agency is the body in charge of coordinating and monitoring the application of the norms stipulated...[including] to monitor the application and observance of the norms stipulated in this Code of Conduct."
} 
consensus. Such a consensus can only be reached by a co-ordinating mechanism - such as a college of ethics advisors.

\section{Dealing with Shared Competence for Ethics Regulation: the Need for a College of Ethics Counsellors}

Romanian administrative law requires the co-ordination of ethics counsellors' competencies. Figure 11 has already shown the highly disarticulated nature of Romanian legislation governing ethics work - militating for a unified approach to ethics at the regulatory level. The NACS has the authority to make ethics policy, but not to enforce it. Each agency has the power to enforce ethics policy - but (to a large extent) does not have the competence to create such policy. As previously discussed, ethics regulation represents a shared competence between the NACS and the agencies which they regulate. A counsel comprising representatives of both authorities should determine ethics-related policy and procedures affecting the implementation of these policies. Such co-ordination would ensure that the development of different ethics doctrines and even procedures between agencies does not lead to a loss of predictability and consistency of the application of those rules. ${ }^{75}$ While a set of substantive rights and obligations governing ethics counsellors' work may be too complex to standardise across agencies, the standardisation of a set of procedural rights (and obligations) can be enshrined in hard law.

Romanian ethics regulators should adopt a consensual method of co-ordination instead of a more centralised method. Figure 14 shows the benefits and drawbacks to each possible method of co-ordinating regulatory provisions governing ethics counsellors' work. The NACS does not have sufficient authority to grant specific powers to ethics counsellors - nor does the Agency have the specific day-to-day experience working with ethical issues involved in each agency's work. One the one hand, a formal structure - such as the US Office of Government Ethics - would create an expensive structure which has not been shown to be effective. ${ }^{76}$ Ethics counsellors need to belong administratively to the agencies they advise in order to obtain competencies listed in Figure 13. On the other hand, an ad hoc ethics committee or assembly could not resolve the number co-ordination issues previously cited. ${ }^{77}$ An intermediary organisational form - such as a standing college - offers the best hope of resolving the co-ordination issues involved in setting up a working government ethics programme without creating an overly bureaucratic and inefficient structure. ${ }^{78}$

\footnotetext{
${ }^{75}$ A consistent body of administrative law would not favour one service user (or public official) over another simply because of the organisational unit with which he or she interacts. Clearly, ethics related doctrine in the customs agency allowed ethics counsellors to provide extensive counselling services, whereas no such rights existed in local administrations, then customs staff receive an unfair amenity. Such an amenity may be justified by the nature of customs work (and thus no value judgment can be taken a priori). However, if all government agencies agree to such a situation, then such a situation could not be deemed unfair (at least in the eyes of the public administration).

${ }^{76}$ See MACKENZIE \& HAFKEN, infra note 26.

${ }^{77}$ Only $30 \%$ of EU member states have such ethics commissions or committees. The general lack of effectiveness of ad hoc ethics commissions militates against having such structures, Demmke et al., supra note 12 at 91.

${ }^{78}$ A detailed discussion of organisational theory (as it applies to the optimal structure of an government ethics institution) would take us outside the reasonable scope of this paper. For an extensive discussion of organisational design issues related to government ethics institutions, see George Frederickson and Richard Ghere, Ethics IN PUBLIC MANAGEMENT, 2005.
} 
Figure 14: Optimal Organisational Structure for Engaging the Ethics Regulating

\begin{tabular}{|l|l|l|l|}
\hline & Pros & Cons & Conclusion \\
\hline NACS takes lead & $\begin{array}{l}\text { Has strongest mandate in law and } \\
\text { specialists in ethics issues. }\end{array}$ & $\begin{array}{l}\text { If the NACS takes the lead on } \\
\text { ethics regulation, the agencies } \\
\text { will ignore their mandates (as } \\
\text { they currently do). }\end{array}$ & Not recommended \\
\hline Agency takes lead & $\begin{array}{l}\text { The agency knows best the } \\
\text { specific ethical dilemmas it faces } \\
\text { (for example, customs ethics are } \\
\text { different than the ethics of } \\
\text { medical practitioners). }\end{array}$ & $\begin{array}{l}\text { If agencies take the lead, the } \\
\text { NACS fails its legislative } \\
\text { mandate to regulate ethics - } \\
\text { leading to possible very different } \\
\text { regulations across agencies. }\end{array}$ & Not recommended \\
\hline $\begin{array}{l}\text { Formal joint work } \\
\text { structure }\end{array}$ & $\begin{array}{l}\text { Clarifies ambiguous distribution } \\
\text { of competencies and signals } \\
\text { importance of ethical issues in } \\
\text { public administration. }\end{array}$ & $\begin{array}{l}\text { Creates another, expensive } \\
\text { bureaucratic structure. Historical } \\
\text { experience of ethics offices } \\
\text { patchy. }\end{array}$ & Not recommended \\
\hline $\begin{array}{l}\text { Ad hoc ethics } \\
\text { committees }\end{array}$ & $\begin{array}{l}\text { Assemble the most relevant } \\
\text { people to take decisions on } \\
\text { specific issues. }\end{array}$ & $\begin{array}{l}\text { Can not engage in follow-up nor } \\
\text { promulgate administrative law. }\end{array}$ & Not recommended \\
\hline $\begin{array}{l}\text { Informal, } \\
\text { permanent } \\
\text { structure(“College } \\
\text { Model”) }\end{array}$ & $\begin{array}{l}\text { ethical regulations as required } \\
\text { without excess formalism. }\end{array}$ & $\begin{array}{l}\text { Potential confusion and excess } \\
\text { complexity if College becomes a } \\
\text { political power within the } \\
\text { administration. }\end{array}$ & Recommended \\
\hline
\end{tabular}

Source: authors.

Such a consensual co-ordinating body - a College of Ethics Counsellors - would have several functions. Such a body would function as ethics counsellors' professional body. As in many other countries (such as the US and France), such a professional body would guarantee ethics counsellors' independence and ensure they have a body with which to share findings. ${ }^{79}$ The College of Ethics Counsellors would also help ensure that ethics counsellors issue incentive-compatible advisories and regulations. As previously noted, most ethics work comprises soft law - as judgment guides a counsellor's advice more than well-defined rules. Ethics counsellors are likely to follow regulations more closely if they help to create them. Only by some form of consensus among ethics counsellors can they arrive at advisories which Romanian civil servants will widely adopt. ${ }^{80}$ The College can also act as a decision-making body for awards to members. Such awards would be given for advice leading to the major reduction of risk or safeguard of state resources.

The creation of a College of Ethics Counsellors requires a power-sharing arrangement between the NACSs and line ministries which only a regulation (or set of regulations) can create. Figure 15 shows how such a College would work. Line ministries - including the NACS -- would agree to the ex officio secondment of ethics counsellors for membership in this professional membership organisation. Like internal auditors, these ethics counsellors have independence, objectivity and other attributes defined by executive regulation.

\footnotetext{
${ }^{79}$ In many countries, the government employees' labour unions have special associations or activities focused on public sector employee's ethics. The US Council on Governmental Ethics Laws (COGEL) represents one prominent example.

${ }^{80}$ For a critique of the strongly neo-classical paradigm to public administrative ethics which we follow, see Ruth Grant, Ethics and Incentives: A Political Approach, 100 AM. PoL. SCI. REV. 1, 2006.
} 
Figure 15: Unifying Ethics Policy and Law for Romanian Civil Servants

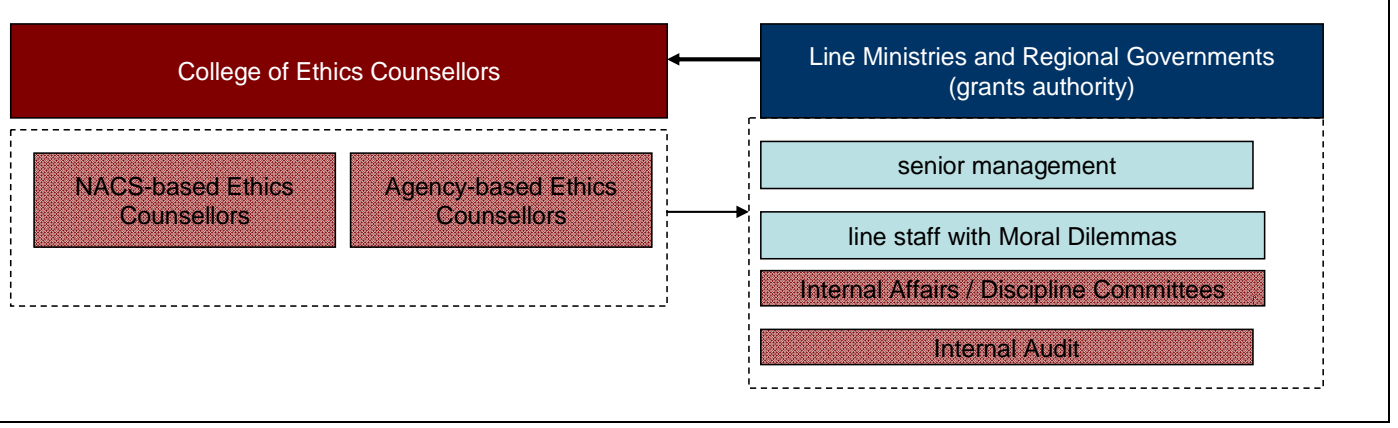

\section{The Method of Adopting a Model Ethics Counsellors Regulation}

The effective implementation of Romania's ethics legal framework requires that executive agencies pass a code of conduct regulation. ${ }^{81}$ Figure 16 depicts a model code of conduct regulation - which would be adopted by each Romanian agency. The first substantive section would deal with the selection and appointment of ethics counsellors. As a profession, ethics counsellors - like other professionals working in executive agencies like auditors or policy analysts - should have specialised training. Ethics counsellors should also receive high-powered incentives and other motivation of accepting the assignment of an ethics counsellor - an assignment which imposes additional obligations on their current job. ${ }^{82}$ The first section of the regulation would also provide incentives - as allowed by law for encouraging ethics counsellors to assume the extra obligations imposed on them by law.

The subsequent sections provide with the basis for the creation of legal doctrines we describe in this paper (based on the implied powers given to ethics counsellors by Romanian law). The regulation would establish the procedures by which ethics counsellors use the specific doctrinal tests (described in Figure 12). The regulation would also establish the procedures by which ethics counsellors can apply these doctrines in specific cases. The regulation would outline statutory rights and obligations related to providing ethics-related counselling services and establish procedures for complying with those statutory obligations. For example, this section would cover how records for whistleblowing should be kept, the types of situations in which the ethic counsellor must refer the case to the agency's legal department and protections for the advisee's confidentiality.

\footnotetext{
${ }^{81}$ The definition of effective implementation of an ethics law bedevils lawmakers. Professors Mackenzie and Hafken provide a sweeping and comprehensive study of ethics regulations in the US, showing that they failed to improve ethics in the US civil service because of poorly defined objectives. See supra note 13.

${ }^{82}$ Ethics counsellors in all Romanian government agencies have been selected by their agencies to assume the additional responsibilities of their office. Most ethics counsellors work in the human resources departments of their respective agencies. The design of these incentives comprises an interesting paper in its own right. To keep this paper at a reasonable length, we focus on the more interesting issues related to the creation of administrative legal doctrines and avoid a discussion of self-enforcing, incentive compatible provisions regulating the work of ethics counsellors.
} 
Figure 16: Model Operational Instruction Related to the Romanian Government Ethics Officers

SUMMARY OF THE OPERATIONAL INSTRUCTION ON ETHICS OFFICERS

Overview and Background, Regulatory Impact and Risk assessment

\section{ANTECEDENTS}

Chapter 1: Antecedents

\section{APPOINTMENT AND CAREER ISSUES FOR ETHICS COUNSELLORS}

Chapter 2: Assignment and Qualifications of Ethics Counsellors

Chapter 3: Incentive Structure for Ethics Counsellors

Chapter 4: Publicity of Ethics Counsellors

\section{AGENCY-LEVEL TESTS FOR GENERAL ETHICAL PRINCIPLES AND BROAD LEGAL PRINCIPLES}

Chapter 5: Interpreting Whistleblower Protection Principles

Chapter 6: Interpreting Legal Principles

POWERS OF DELEGATED AUTHORITY

Chapter 7: Authority to Act as Mediator

Chapter 8: Injunctions and Certiorari Relief (Suspension Orders and Orders Related to Witness Protection)

Chapter 9: Internal Whistleblowers and Ombudsman's Functions

\section{CASE MANAGEMENT}

Chapter 10: Introductory Procedure for Consultations

Chapter 11: Procedure for Dealing with Unrecorded Consultations

Chapter 12: Procedures in Recorded and Anonymous Consultations

Chapter 13: Dealing with Ethics Counsellor Liability

\section{INSTITUTIONAL ARRANGEMENTS}

Chapter 14: Relations Between Ethics Councillors And Disciplinary Committees

Chapter 15: Relations Between Ethics Councillors and the NACS

Chapter 16: Establishment of the College of Ethics Councillors

Chapter 17: Disciplinary Sub-Committee of the College of Ethics Councillors

Chapter 18: Ensuring Quality of Ethics Counsellor's Reports

\section{FINAL DISPOSITIONS}

Chapter 19: Obligation to Consult on Present Instruction

Chapter 20. Changes in the Legal Framework

Chapter 21. Execution

The regulation would also define the institutional structure and the method of implementing the regulation in the agency. As previously discussed, the agency must define clearly the competencies delegated to the ethics counsellor. The regulation can also define the way in which its ethics counsellors work within the College of Ethics Counsellors. During the adoption process, though, the NACS should take the lead in negotiating the implementation of the code of conduct regulation across public agencies. As shown in Figure 17, the NACS should negotiate with agency-level ethics counsellors about how a model regulation would be adopted within their agency (using the regulation shown in Figure 16 above as a guide). Once the NACS and the agencies' ethics counsellors reach agreement on the wording of the final regulations, the heads of the various Romanian agencies must adopt the regulation. The head, along with his or her legal counsel, would revise the code of conduct regulation and eventually sign the regulation into his or her agency’s administrative law. 


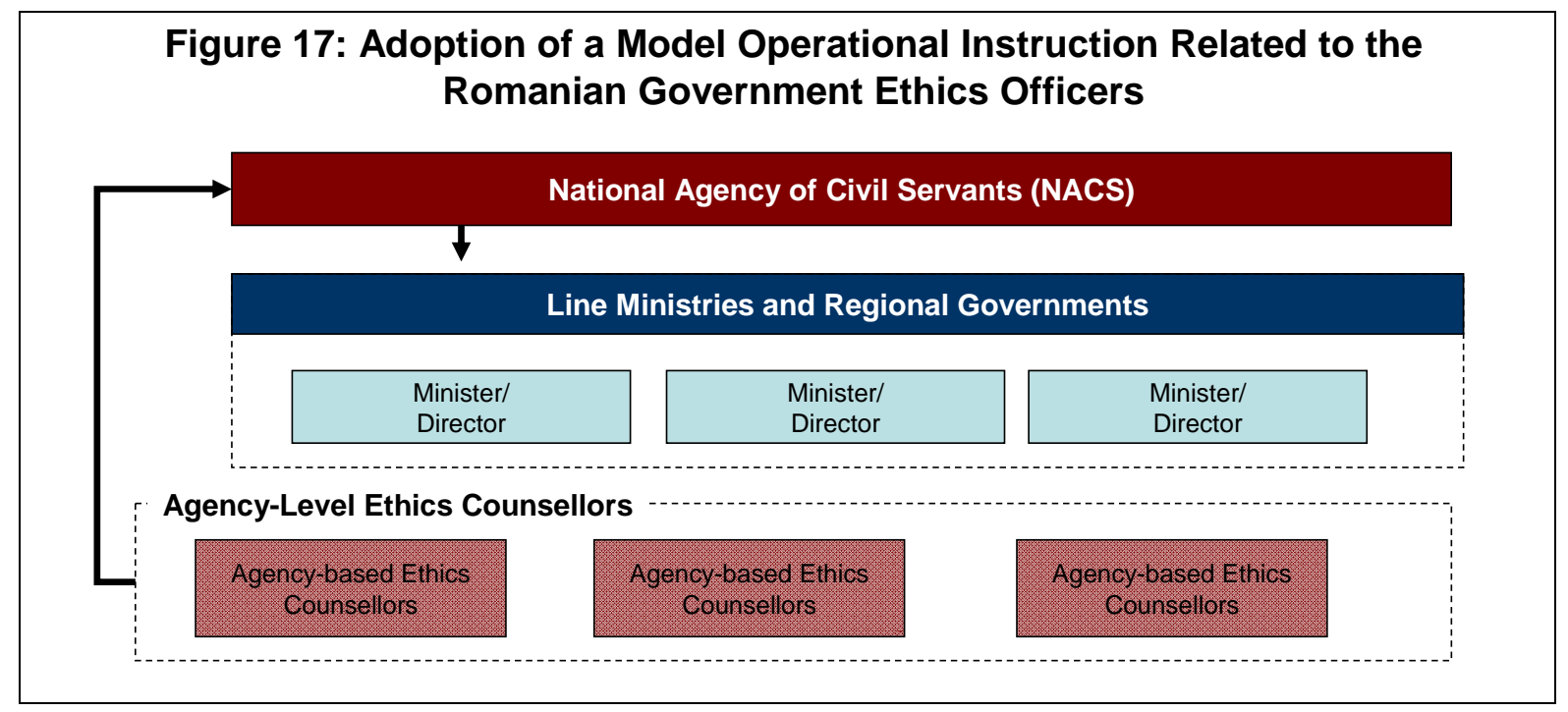

What happens if an agency passes a "bad" ethics regulation? For example, the head of the Ministry of Environment may adopt an ethics regulation which the NACS or the College of Ethics Counsellors disapproves of. In this case, the NACS has the legal right to require amendments - as granted by article 20 of the Code of Conduct Law. ${ }^{83}$ Once the College of Ethics Counsellors starts functioning, the College should engage in such enforcement - as it has representatives from the NACS as well as representatives from other government agencies who can apply peer pressure on the offending agency. Such an approach deals the distinctly political as well as bureaucratic nature of these codes of conduct. ${ }^{84}$

Such a consensual approach to implementing an ethics regulation in Romania balances the widely advocated "participatory approaches" to code of conduct work with the need learn from previous conflicts. Figure 18 shows the way that many ethics laws - particularly in Central and Eastern Europe - have been adopted. ${ }^{85}$ The Romanian code of conduct work seems strongly influenced by the diffusionist approach to ethics work. The similarities in codes of conduct between countries in the region (as shown in Figures 3) suggests that the same international organisations provided consulting services to these countries. ${ }^{86}$ Civil servants in these Central and Eastern European countries widely discussed the codes of conducts and ethics models presented to them by international consultants before adoption using the techniques popular in the participatory approach method. Unlike in many western European countries, however, these Central and Eastern European countries did not consult the case history of administrative disputes in order to help define the principles used for

\footnotetext{
${ }^{83}$ As the Code of Conduct Law contains very few enforcement mechanisms, the Minister may be unlikely to revise the regulation. Enforcement clearly depends on the ability (and willingness) of the NACS to issue censures or even seek remedies at a higher administrative level, such as in the Cabinet of Ministers.

${ }^{84}$ Professor Dobel provides a powerful narrative showing how ethics codes in the US underwent extensive negotiating and bureaucratic politics. See Patrick Dobel, The realpolitik of ethics codes: An implementation approach to public ethics, In George Frederickson, ETHICS AND PUBLIC ADMINISTRATION, 1993.

${ }^{85}$ Saarniit provides an enlightening story of the adoption of an ethics framework in the case of Estonia, see Saarniit, supra note 6.

${ }^{86}$ The UNDP provides an overview of the types of assistance it and other organisations have been providing in the area of civil servant ethics. See UNDP, CASE EVIDENCE ON ETHICS AND VALUES IN CIVIL SERVICE REFORMS, available online.
} 
deciding ethics-related cases. ${ }^{87}$ Romania still has a long way to go in using such conflict resolution in its code of conduct work. ${ }^{88}$

\section{Figure 18: Three Methods of Lawmaking on Public Officials’ Codes of Conduct}

In general, three methods exist of adopting legislation on public officials' codes of conduct: diffusionist, participatory, and conflict approaches.

Diffusionist approach - takes code of conduct work from other countries, or international organisations like the Council of Europe or UNDP, and attempts to adopt as closely as possible. Most codes of conduct in Central Europe - including Romania's law - stem from this approach. Most derive from already established codes existing - particularly in US and UK.

Participatory approach - strongly advocated by American scholars and practitioners, this approach argues that codes of conduct must result from extensive consultation with government agency staff. A facilitator, often a very coercive one, collects statements about civil servants' ethics and "distills" them into a code. Central European countries also like such a warm, fuzzy approach to civil servant ethics.

Conflict resolution approach - codes of conduct should result from actual resolutions to previous ethical conflicts. These codes derive inspiration from administrative judgements and court decisions as the primary resource material for civil servant (and to a lesser extent public official) codes of conduct.

In the public administration ethics literature, increasing attention is being focused on the conflict resolution approach for three reasons. First, previous court decisions and judgements already constitute law - thus not requiring code drafters to re-invent the wheel. Second, codes of conduct developed using participatory approaches often represent wishes instead of hard comprises. Participants developing these codes have few incentives to act according to them, except for voluntary compliance. Third, the diffusionist approach has encouraged predatory behaviour by consultants who come, develop a code of conduct - often copied from their own home country - and then they move on to the next assignment. Most Central European countries are now wary of experts peddling codes of conduct.

Source: authors.

\section{Conclusions}

The effective implementation of government code of conduct work in Romania - and we describe the problems in defining efficacy - requires the multi-agency adoption of ethics regulations. Such regulations would clarify the substantive and procedural rights provided by legislative acts such as the Code of Conduct Law. In our paper, we discuss the ways in which regulatory drafters can adopt a doctrinal approach toward implementing government codes of conduct in a civil law system like Romania's. We specifically enumerate the rights which ethics counsellors, who work in Romania's various government agencies, have in supervising and enforcing ethics-related legislation. We argue that many of these rights (and obligations) derive from implied powers given by Romanian law. A key right constitutes the right to define ethics-related doctrines which can be administratively relied upon by ethics counsellors, their superiours and the civil servants they advise. By adopting the model regulation we provide in this paper, we think it will go a long way toward making allowing Romanian government agencies to comply with ethics-related legislation and make Romania a leader in the region in government ethics.

\footnotetext{
${ }^{87}$ Researchers in New Institutional Economics have fruitfully showed how the resolutions to administrative disputes create Pareto efficient administrative legal institutions. For a background, see Jean-Michel Josselin and Alain Marciano, Administrative Law and Economics, in Jurgen Backhaus, THE ELGAR COMPANION TO LAW AND ECONOMICS, 2005.

${ }^{88}$ College of Ethics Counsellors can help, as they can consider administrative disputes from various agencies to arrive at principles accepted by the wider public sector.
} 